\title{
LEVEL II SCOUR ANALYSIS FOR BRIDGE 41 (ANDOVT00110041) on STATE ROUTE 11, crossing the MIDDLE BRANCH WILLIAMS RIVER, ANDOVER, VERMONT
}

Open-File Report 97-771

Prepared in cooperation with

VERMONT AGENCY OF TRANSPORTATION

and

FEDERAL HIGHWAY ADMINISTRATION

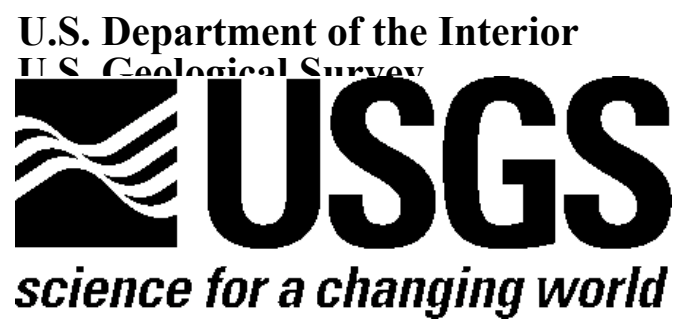




\section{LEVEL II SCOUR ANALYSIS FOR BRIDGE 41 (ANDOVT00110041) on STATE ROUTE 11, crossing the MIDDLE BRANCH WILLIAMS RIVER, ANDOVER, VERMONT \\ By EMILY C. WILD and ROBERT E. HAMMOND}

U.S. Geological Survey

Open-File Report 97-771

Prepared in cooperation with

VERMONT AGENCY OF TRANSPORTATION

and

FEDERAL HIGHWAY ADMINISTRATION 


\title{
U.S. DEPARTMENT OF THE INTERIOR BRUCE BABBITT, Secretary
}

\author{
U.S. GEOLOGICAL SURVEY \\ Mark Schaefer, Acting Director
}

For additional information write to:

District Chief

U.S. Geological Survey 361 Commerce Way

Pembroke, NH 03275-3718
Copies of this report may be purchased from:

U.S. Geological Survey

Branch of Information Services

Open-File Reports Unit

Box 25286

Denver, CO 80225-0286 


\section{CONTENTS}

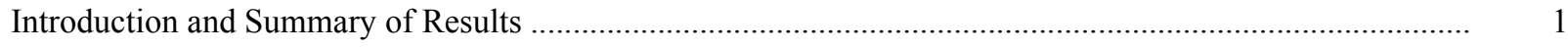

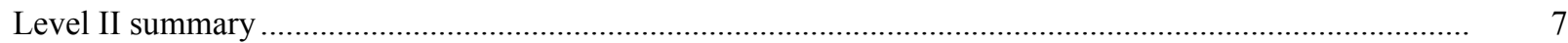

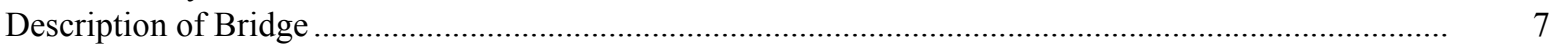

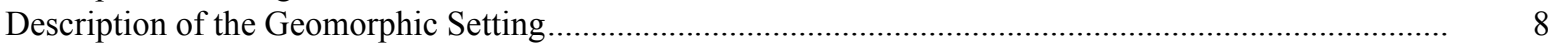

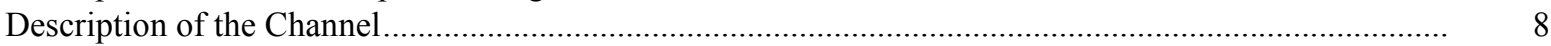

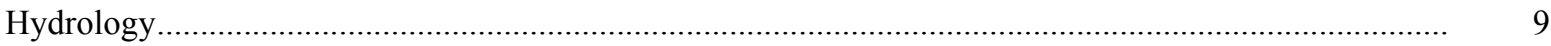

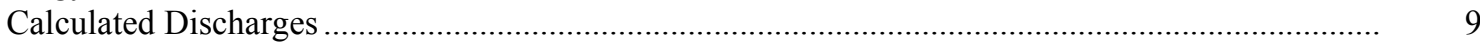

Description of the Water-Surface Profile Model (WSPRO) Analysis ......................................................... 10

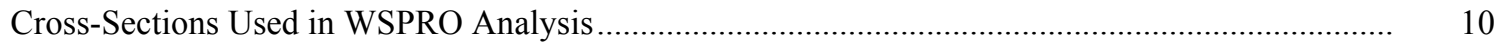

Data and Assumptions Used in WSPRO Model ...........................................................................

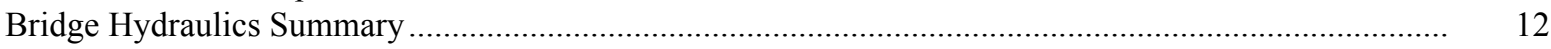

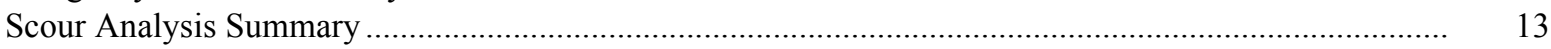

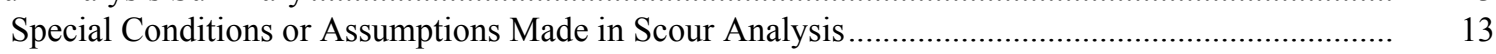

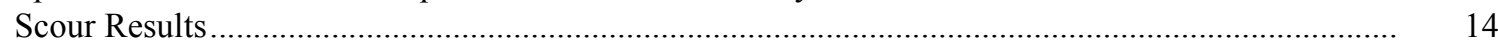

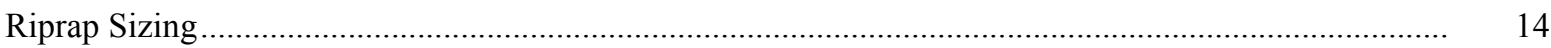

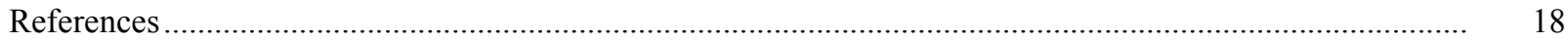

Appendixes:

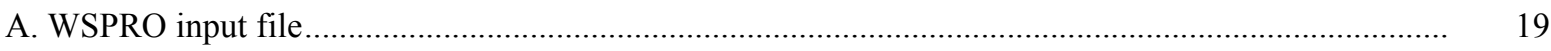

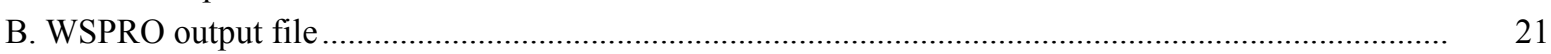

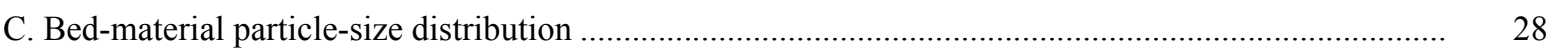

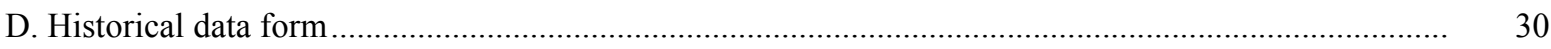

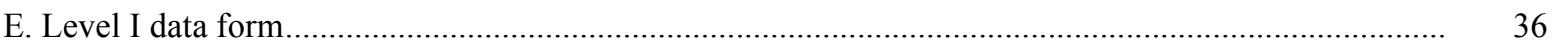

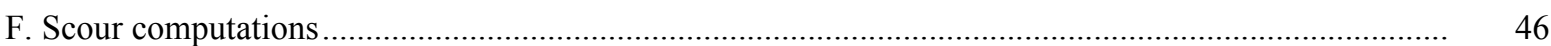

\section{FIGURES}

1. Map showing location of study area on USGS 1:24,000 scale map ........................................................

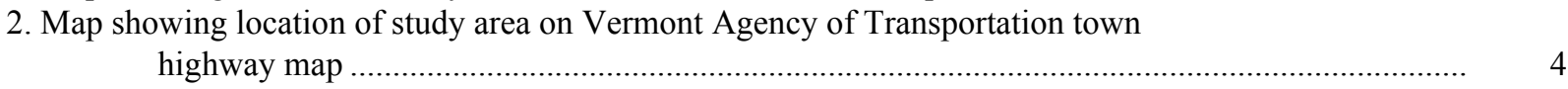

3. Structure ANDOVT00110041 viewed from upstream (September 10, 1996) .......................................... 5

4. Downstream channel viewed from structure ANDOVT00110041 (September 10, 1996)......................... 5

5. Upstream channel viewed from structure ANDOVT00110041 (September 10, 1996)................................. 6

6. Structure ANDOVT00110041 viewed from downstream (September 10, 1996)....................................... 6

7. Water-surface profiles for the 100- and 500-year discharges at structure

ANDOVT00110041 on State Route 11, crossing the Middle Branch Williams River,

Andover, Vermont.

8. Scour elevations for the 100- and 500-year discharges at structure

ANDOVT00110041 on State Route 11, crossing the Middle Branch Williams River,

Andover, Vermont.

\section{TABLES}

1. Remaining footing/pile depth at abutments for the 100-year discharge at structure

ANDOVT00110041 on State Route 11, crossing the Middle Branch Williams River,

Andover, Vermont

2. Remaining footing/pile depth at abutments for the 500-year discharge at structure

ANDOVT00110041 on State Route 11, crossing the Middle Branch Williams River,

Andover, Vermont 


\begin{tabular}{|c|c|c|}
\hline Multiply & By & To obtain \\
\hline \multicolumn{3}{|c|}{ Length } \\
\hline inch (in.) & 25.4 & millimeter (mm) \\
\hline foot $(\mathrm{ft})$ & 0.3048 & meter $(\mathrm{m})$ \\
\hline mile (mi) & 1.609 & kilometer (km) \\
\hline & Slope & \\
\hline foot per mile ( $\mathrm{ft} / \mathrm{mi})$ & 0.1894 & meter per kilometer $(\mathrm{m} /$ \\
\hline \multicolumn{3}{|l|}{ km) } \\
\hline \multicolumn{3}{|c|}{ Area } \\
\hline \multirow[t]{2}{*}{ square mile $\left(\mathrm{mi}^{2}\right)$} & 2.590 & \multirow[t]{2}{*}{ square kilometer $\left(\mathrm{km}^{2}\right)$} \\
\hline & Volume & \\
\hline \multirow[t]{2}{*}{ cubic foot $\left(\mathrm{ft}^{3}\right)$} & 0.02832 & \multirow[t]{2}{*}{ cubic meter $\left(\mathrm{m}^{3}\right)$} \\
\hline & Velocity and Flow & \\
\hline foot per second (ft/s) & 0.3048 & meter per second $(\mathrm{m} / \mathrm{s})$ \\
\hline cubic foot per second $\left(\mathrm{ft}^{3} / \mathrm{s}\right)$ & 0.02832 & cubic meter per second \\
\hline \multicolumn{3}{|l|}{$\left(\mathrm{m}^{3} / \mathrm{s}\right)$} \\
\hline cubic foot per second per & \multirow[t]{3}{*}{0.01093} & \multirow{3}{*}{$\begin{array}{l}\text { cubic meter per } \\
\text { second per square } \\
\text { kilometer }\left[\left(\mathrm{m}^{3} / \mathrm{s}\right) / \mathrm{km}^{2}\right]\end{array}$} \\
\hline square mile & & \\
\hline$\left[\left(\mathrm{ft}^{3} / \mathrm{s}\right) / \mathrm{mi}^{2}\right]$ & & \\
\hline
\end{tabular}

\section{OTHER ABBREVIATIONS}

$\begin{array}{lrl}\text { BF } & \text { bank full } & \text { LWWleft wingwall } \\ \mathrm{cfs} & \text { cubic feet per second } & \text { MCmain channel } \\ \mathrm{D}_{50} & \text { median diameter of bed material } & \text { RABright abutment } \\ \mathrm{DS} & \text { downstream } & \text { RABUT face of right abutment } \\ \mathrm{elev} & \text { elevation } & \text { RBright bank } \\ \mathrm{f} / \mathrm{p} & \text { flood plain } & \text { ROBright overbank } \\ \mathrm{ft}^{2} & \text { square feet } & \text { RWWright wingwall } \\ \mathrm{ft} / \mathrm{ft} & \text { feet per foot } & \text { THtown highway } \\ \mathrm{JCT} & \text { junction } & \text { UBunder bridge } \\ \text { LAB } & \text { left abutment } & \text { USupstream } \\ \text { LABUT } & \text { face of left abutment } & \text { USGSUnited States Geological Survey } \\ \text { LB } & \text { left bank } & \text { VTAOTVermont Agency of Transportation } \\ \text { LOB } & \text { left overbank } & \text { WSPROwater-surface profile model }\end{array}$

In this report, the words "right" and "left" refer to directions that would be reported by an observer facing downstream.

Sea level: In this report, "sea level" refers to the National Geodetic Vertical Datum of 1929-- a geodetic 


\title{
LEVEL II SCOUR ANALYSIS FOR BRIDGE 41 (ANDOVT00110041) ON STATE ROUTE 11, CROSSING THE MIDDLE BRANCH WILLIAMS RIVER, ANDOVER, VERMONT
}

\author{
By Emily C. Wild and Robert E. Hammond
}

\section{INTRODUCTION AND SUMMARY OF RESULTS}

This report provides the results of a detailed Level II analysis of scour potential at structure ANDOVT00110041 on State Route 11 crossing the Middle Branch Williams River, Andover, Vermont (figures 1-8). A Level II study is a basic engineering analysis of the site, including a quantitative analysis of stream stability and scour (U.S. Department of Transportation, 1993). Results of a Level I scour investigation also are included in Appendix E of this report. A Level I investigation provides a qualitative geomorphic characterization of the study site. Information on the bridge, gleaned from Vermont Agency of Transportation (VTAOT) files, was compiled prior to conducting Level I and Level II analyses and is found in Appendix D.

The site is in the Green Mountain section of the New England physiographic province in southeastern Vermont. The $12.1-\mathrm{mi}^{2}$ drainage area is in a predominantly rural and forested basin. In the vicinity of the study site, the surface cover is grass on the upstream right overbank while the immediate banks have dense woody vegetation. The upstream left overbank and downstream right overbank are brushland. The downstream left overbank is forested.

In the study area, the Middle Branch Williams River has an incised, sinuous channel with a slope of approximately $0.018 \mathrm{ft} / \mathrm{ft}$, an average channel top width of $71 \mathrm{ft}$ and an average bank height of $4 \mathrm{ft}$. The channel bed material ranges from gravel to boulders with a median grain size $\left(\mathrm{D}_{50}\right)$ of $85.0 \mathrm{~mm}(0.279 \mathrm{ft})$. The geomorphic assessment at the time of the Level I and Level II site visit on September 10, 1996, indicated that the reach was laterally unstable due to a cut-bank present on the upstream right bank and a wide channel bar with vegetation in the upstream reach.

The State Route 11 crossing of the Middle Branch Williams River is a 46-ft-long, two-lane bridge consisting of a concrete 44-foot tee-beam span (Vermont Agency of Transportation, written communication, March 29, 1995). The opening length of the structure parallel to the bridge face is $42 \mathrm{ft}$. The bridge is supported by vertical, concrete abutments with wingwalls. The channel is skewed approximately 35 degrees to the opening while the opening-skew-toroadway is zero degrees. 
A scour hole $0.8 \mathrm{ft}$ deeper than the mean thalweg depth was observed along the downstream end of the left abutment and downstream left wingwall during the Level I assessment. Type2 stone fill (less than 36 inches diameter) protects the upstream end of the upstream left wingwall, the downstream ends of the downstream left and right wingwalls and the downstream right road embankment. Type-3 stone fill protects the upstream end of the upstream right wingwall and the upstream right bank. Additional details describing conditions at the site are included in the Level II Summary and Appendices D and E.

Scour depths and recommended rock rip-rap sizes were computed using the general guidelines described in Hydraulic Engineering Circular 18 (Richardson and others, 1995). In addition, the incipient roadway-overtopping discharge was determined and analyzed as another potential worst-case scour scenario. Total scour at a highway crossing is comprised of three components: 1) long-term streambed degradation; 2) contraction scour (due to accelerated flow caused by a reduction in flow area at a bridge) and; 3 ) local scour (caused by accelerated flow around piers and abutments). Total scour is the sum of the three components. Equations are available to compute depths for contraction and local scour and a summary of the results of these computations follows.

Contraction scour for all modelled flows ranged from 0.0 to $2.1 \mathrm{ft}$. The worst-case contraction scour occurred at the 500-year discharge. Abutment scour ranged from 11.1 to $18.7 \mathrm{ft}$. The worst-case abutment scour occurred at the 500-year discharge. Additional information on scour depths and depths to armoring are included in the section titled "Scour Results". Scoured-streambed elevations, based on the calculated scour depths, are presented in tables 1 and 2. A cross-section of the scour computed at the bridge is presented in figure 8. Scour depths were calculated assuming an infinite depth of erosive material and a homogeneous particle-size distribution.

It is generally accepted that the Froehlich equation (abutment scour) gives "excessively conservative estimates of scour depths" (Richardson and others, 1995, p. 47). Usually, computed scour depths are evaluated in combination with other information including (but not limited to) historical performance during flood events, the geomorphic stability assessment, existing scour protection measures, and the results of the hydraulic analyses. Therefore, scour depths adopted by VTAOT may differ from the computed values documented herein. 


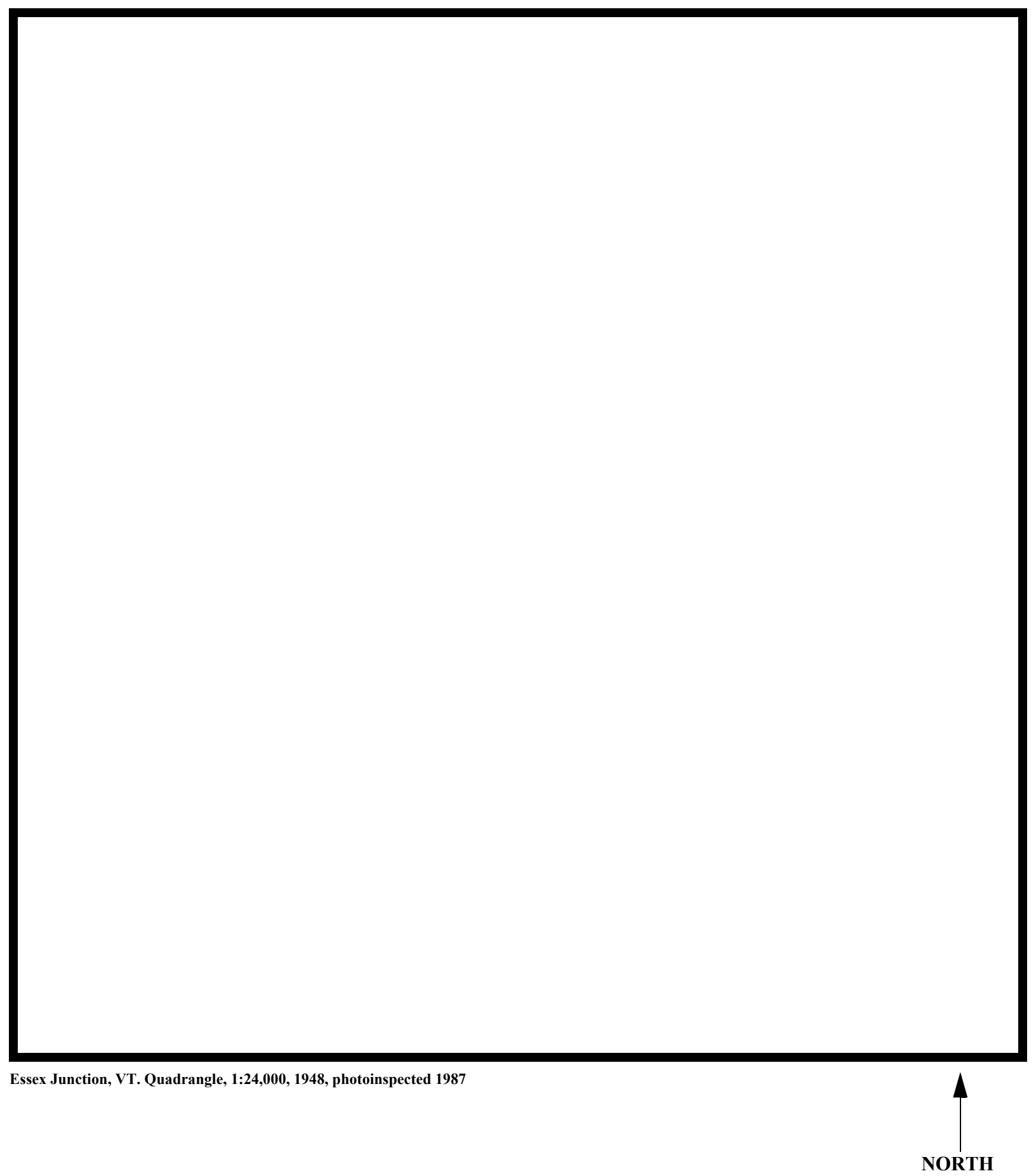

Figure 1. Location of study area on USGS 1:24,000 scale map. 
Figure 2. Location of study area on Vermont Agency of Transportation town highway map. 


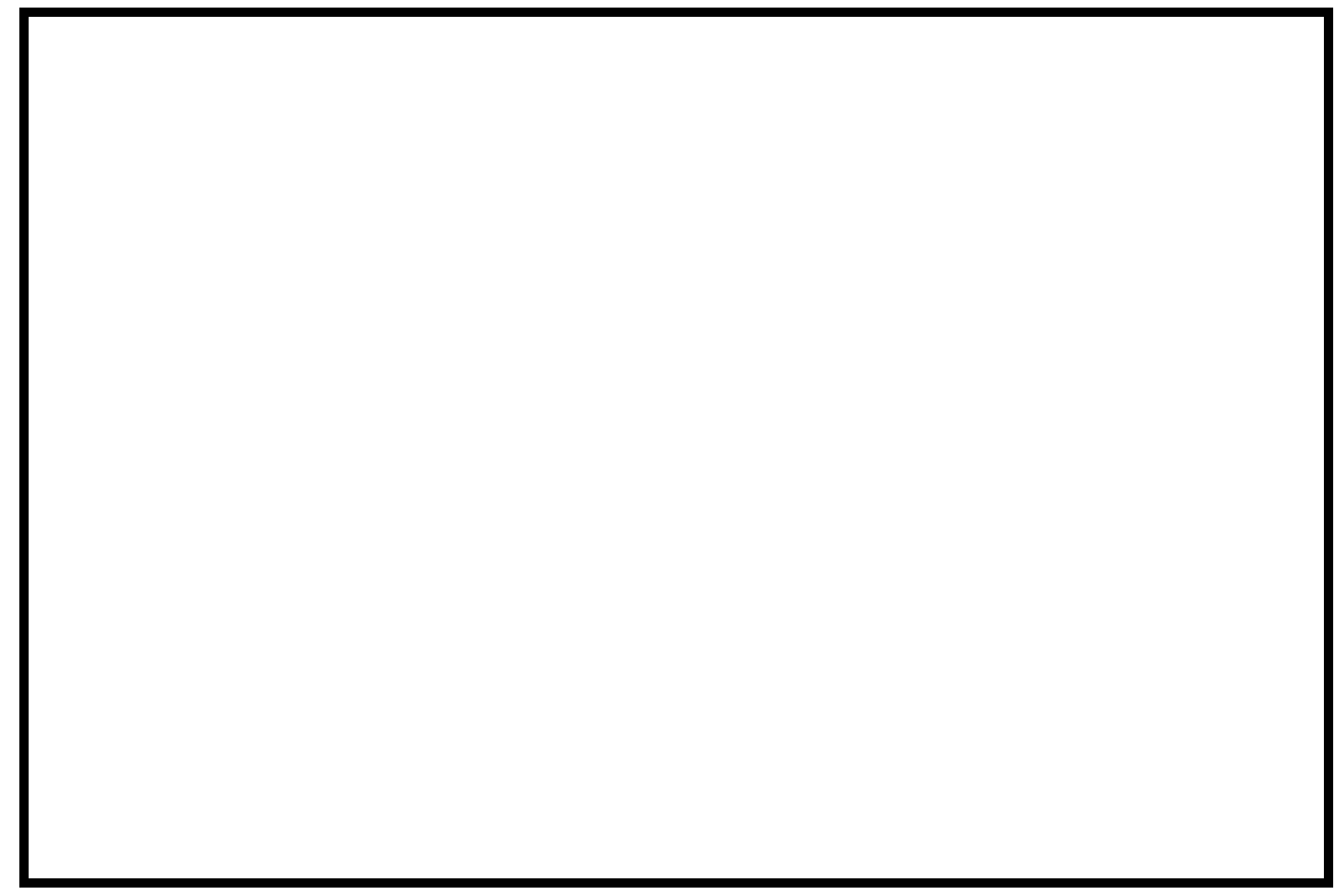

Figure 3. Structure ANDOVT00110041 viewed from upstream (November 8, 1994). 


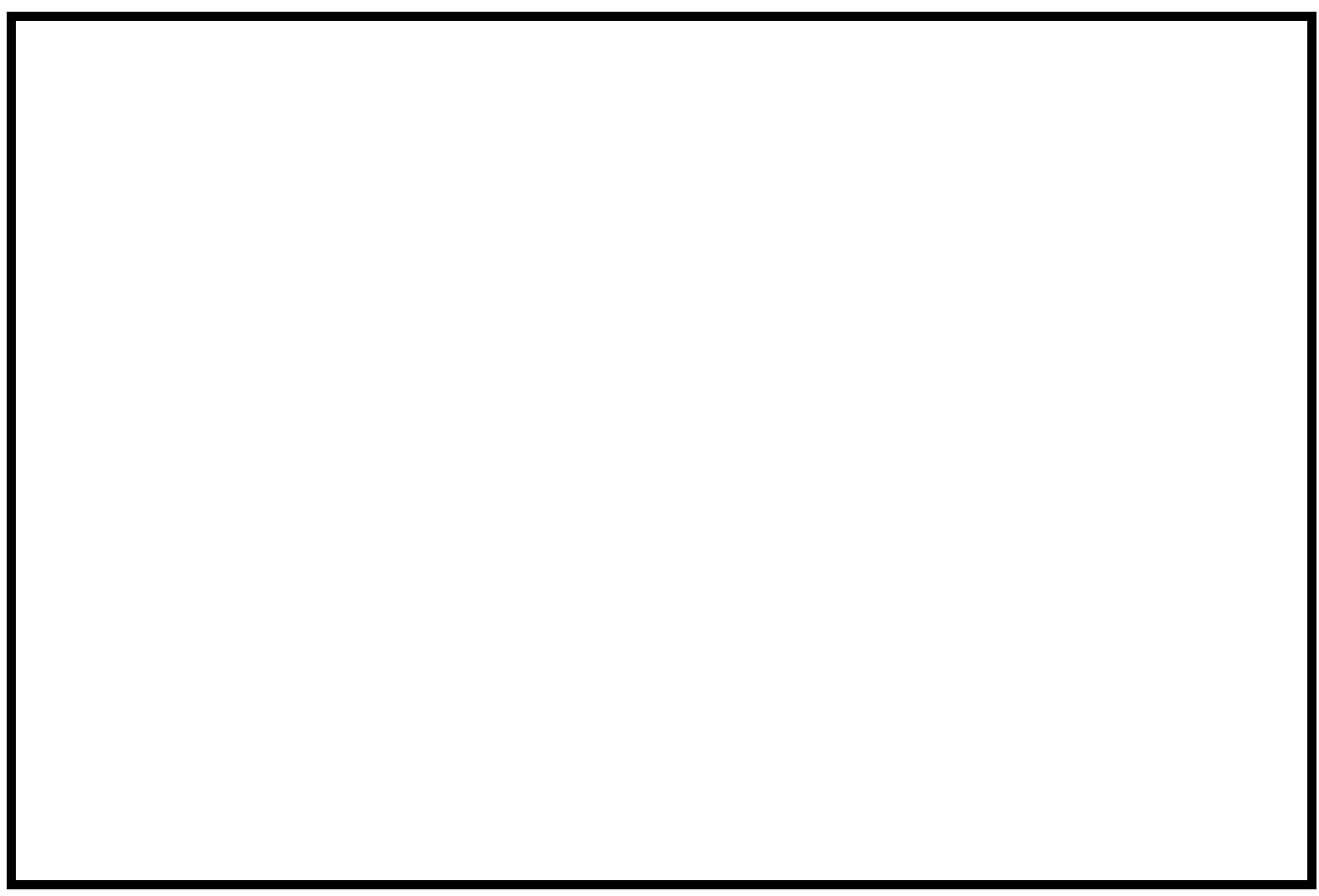

Figure 5. Upstream channel viewed from structure ANDOVT00110041 (November 8, 1994). 


\section{LEVEL II SUMMARY}

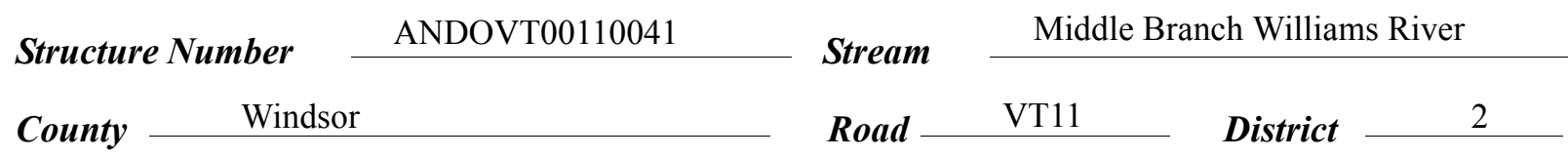

\section{Description of Bridge}

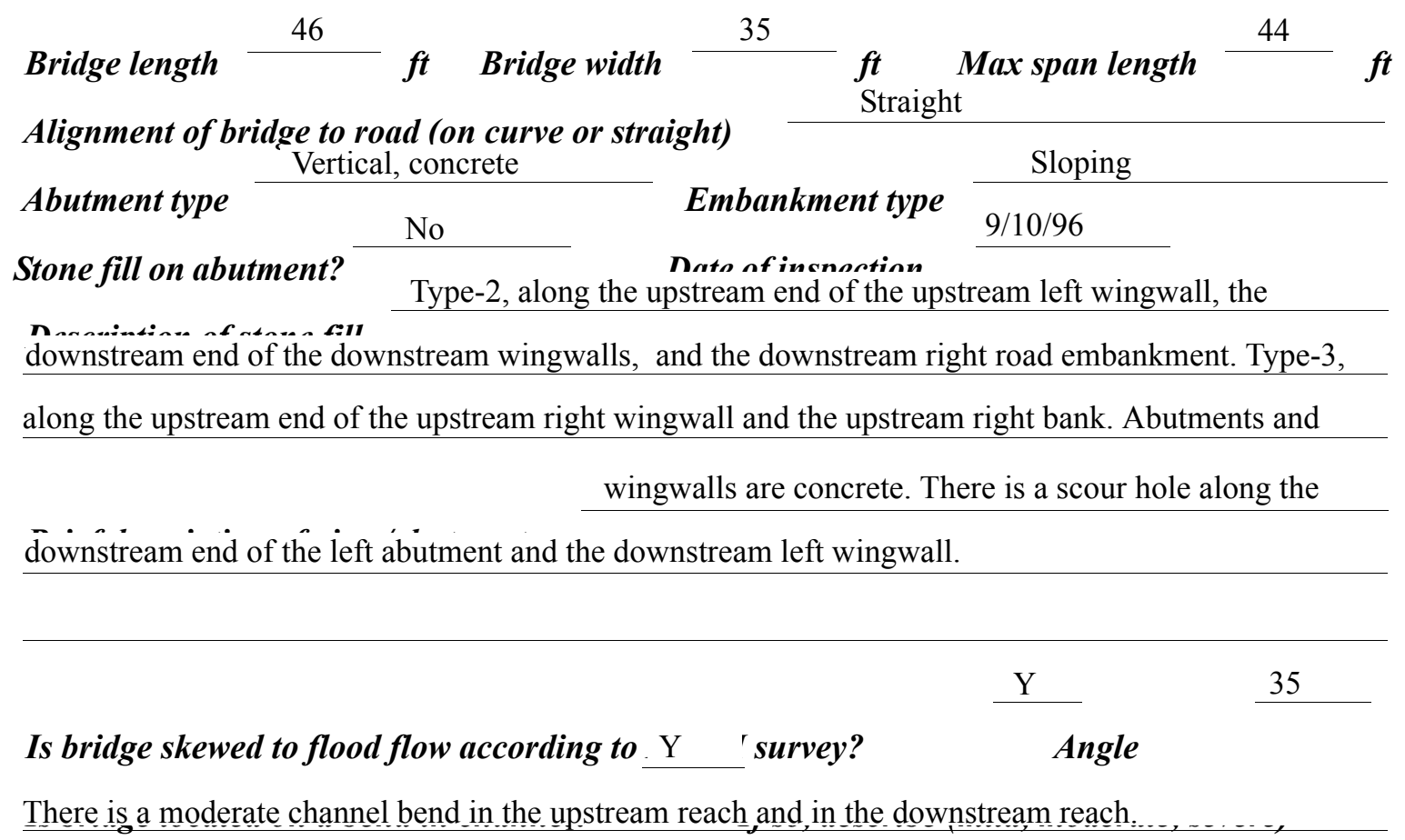

Debris accumulation on bridge at time of Level I or Level II site visit:

\begin{tabular}{|c|c|c|c|}
\hline & $\begin{array}{c}\text { Date of insnortion } \\
9 / 10 / 96 \\
\end{array}$ & $\begin{array}{l}\text { Percent of almminal } \\
\text { blocked inortzontatly }\end{array}$ & $\begin{array}{l}\text { Percent of } \\
\text { blocked verticatty }\end{array}$ \\
\hline I וסטי & $9 / 10 / 96$ & 0 & 0 \\
\hline $\begin{array}{l}\text { Level II } \\
\text { upstream reach. }\end{array}$ & \multicolumn{3}{|c|}{ Moderate. There is some debris caught on boulders and trees in the } \\
\hline
\end{tabular}

None. $9 / 10 / 96$

Doscriho any, foaturos noar ar at tho hridos that mav, affoct flou, (includo ahsorvation dato) 


\section{Description of the Geomorphic Setting}

General topography The channel is located within a narrow, irregular flood plain with steep valley walls on both sides.

Geomorphic conditions at bridge site: downstream (DS), upstream (US)

Date of inspection $\quad 9 / 10 / 96$

DS left: $\quad$ Narrow flood plain with a steep valley wall.

DS right: $\quad$ Narrow flood plain.

US left: $\quad$ Narrow flood plain.

US right: Steep channel bank.

\section{Description of the Channel}

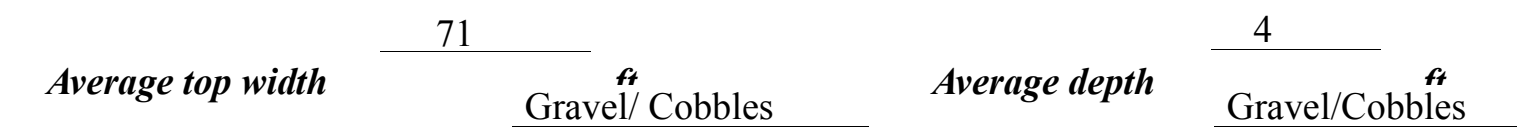

Predominant bed material

Bank material

Sinuous but stable

with alluvial channel boundaries and a narrow flood plain.

$9 / 10 / 96$

Vegetative co 1 Trees and brush.

DS left: $\quad$ Trees and brush.

DS right: $\quad$ Short grass and brush with trees on immediate banks.

US left: $\quad$ Brush, grass and trees.

US right:

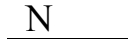

Do banks appear stable? During the 9/10/96 site visit the banks appear to be laterally unstable. Light to moderate fluvial erosion was noted along the upstream right bank. Moderate to severe
date of observatton. fluvial erosion was noted along the downstream left bank.

10/96 noted a vegetated point bar along the right abutment. Describe any obstructions in channel and date of observation. 


\section{Hydrology}

Drainage area $\frac{12.1}{\boldsymbol{m i}^{2}}$

Percentage of drainage area in physiographic provinces: (approximate)

Physiographic province/section New England/ Green Mountain
Percent of drainage area 100

Is drainage area considered rural or urban? — Rural _ Describe any significant urbanization:

Yes

Is there a USGS gage on the stream of interest? Williams River at Brockways Mills, VT USGS gage description 01153500

USGS gage number 103

Gage drainage area $m i^{2}$ No

Is there a lake' -

- ... . ...

$n$

,

$\because$ 


\section{Description of the Water-Surface Profile Model (WSPRO) Analysis}

Datum for WSPRO analysis (USGS survey, sea level, VTAOT plans)

USGS survey

Datum tie between USGS survey and VTAOT plans

To obtain VTAOT datum, add

$569.7 \mathrm{ft}$ to USGS survey.

Description of reference marks used to determine USGS datum. $\quad$ RM1 is a chiseled X on

top of the right end of the downstream curb (elev. $500.11 \mathrm{ft}$, arbitrary survey datum). RM2 is a

chiseled X on top of the left end of the upstream curb (elev. $501.04 \mathrm{ft}$, arbitrary survey datum).

\section{Cross-Sections Used in WSPRO Analysis}

\begin{tabular}{cccl}
\hline${ }^{1}$ Cross-section & $\begin{array}{c}\text { Section } \\
\text { Reference } \\
\text { Distance } \\
(\text { SRD) } \text { in feet }\end{array}$ & $\begin{array}{c}{ }^{2} \text { Cross-section } \\
\text { development }\end{array}$ & \multicolumn{1}{c}{ Comments } \\
\hline EXITX & -42 & 1 & Exit section \\
FULLV & 0 & 2 & $\begin{array}{l}\text { Downstream Full-valley } \\
\text { section (Templated from } \\
\text { EXITX) }\end{array}$ \\
BRIDG & 0 & 1 & $\begin{array}{l}\text { Bridge section } \\
\text { Road Grade section } \\
\text { RDWAY }\end{array}$ \\
APPRO & 19 & 1 & $\begin{array}{l}\text { Approach section as sur- } \\
\text { veyed }\end{array}$ \\
\hline
\end{tabular}

${ }^{1}$ For location of cross-sections see plan-view sketch included with Level I field form, Appendix E.

For more detail on how cross-sections were developed see WSPRO input file. 


\section{Data and Assumptions Used in WSPRO Model}

Hydraulic analyses of the reach were done by use of the Federal Highway Administration's WSPRO step-backwater computer program (Shearman and others, 1986, and Shearman, 1990). The analyses reported herein reflect conditions existing at the site at the time of the study. Furthermore, in the development of the model it was necessary to assume no accumulation of debris or ice at the site. Results of the hydraulic model are presented in the Bridge Hydraulic Summary, Appendix B, and figure 7.

Channel roughness factors (Manning's “ $n$ ”) used in the hydraulic model were estimated using field inspections at each cross section following the general guidelines described by Arcement and Schneider (1989). Final adjustments to the values were made during the modelling of the reach. Channel " $n$ " values for the reach ranged from 0.040 to 0.055 , and overbank " $n$ " values ranged from 0.048 to 0.110 .

Normal depth at the exit section (EXITX) was assumed as the starting water surface. This depth was computed by use of the slope-conveyance method outlined in the user's manual for WSPRO (Shearman, 1990). The slope used was $0.0180 \mathrm{ft} / \mathrm{ft}$, which was calculated from thalweg points surveyed downstream of the bridge.

The approach section (APPRO) was surveyed one bridge length upstream of the upstream face, as recommended by Shearman and others (1986). This section location also provides a consistent method for determining scour variables. 


\section{Bridge Hydraulics Summary}

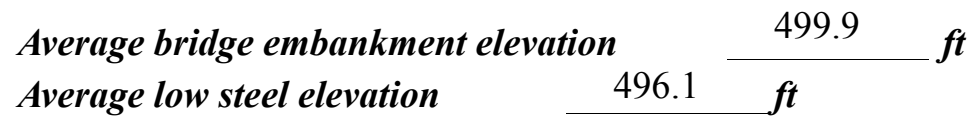

$$
\text { 100-year discharge } \quad 3,270 \quad \mathrm{ft}^{3} / \mathrm{s}
$$

Water-surface elevation in bridge opening $\quad 496.3 \quad f t$

Road overtopping? ___ N Discharge over road __

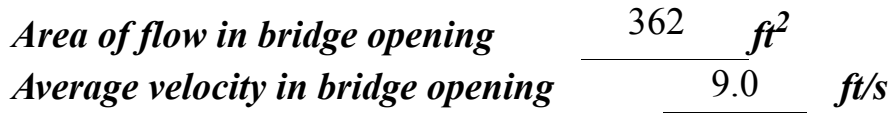

$\begin{array}{lll}\text { Maximum WSPRO tube velocity at bridge } & 12.3 \mathrm{ft} / \mathrm{s}\end{array}$

Water-surface elevation at Approach section with bridge 498.1

Water-surface elevation at Approach section without bridge $\quad \overline{494.6}$

Amount of backwater caused by bridge $\quad 3.5$ it

500-year discharge $\quad 4,810 \quad \mathrm{ft}^{3} / \mathrm{s}$

Water-surface elevation in bridge opening $\quad 496.4 \mathrm{ft}$

Road overtopping? ___ Y Discharge over road _ $\quad 421 \ldots$

Area of flow in bridge opening $\quad 362 \quad \mathrm{ft}^{2}$

Average velocity in bridge opening $12.1 \mathrm{ft} / \mathrm{s}$

Maximum WSPRO tube velocity at bridge 14.3 's

Water-surface elevation at Approach section with bridge 501.1

Water-surface elevation at Approach section without bridge $\quad 496.1$

Amount of backwater caused by bridge $\quad 5.0$.

Incipient overtopping discharge $\quad 4,010 \quad \mathrm{ft}^{3} / \mathrm{s}$

Water-surface elevation in bridge opening $496.4 \quad t$

Area of flow in bridge opening $\quad 362 \quad \mathrm{ft}^{2}$

Average velocity in bridge opening $\quad 11.1 \mathrm{ft} / \mathrm{s}$

Maximum WSPRO tube velocity at bridge $13.1 \mathrm{ft} / \mathrm{s}$

Water-surface elevation at Approach section with bridge

Water-surface elevation at Approach section without bridge

Amount of backwater caused by bridge $\quad 4.4$ it

499.7

495.3 


\section{Scour Analysis Summary}

\section{Special Conditions or Assumptions Made in Scour Analysis}

Scour depths were computed using the general guidelines described in Hydraulic Engineering Circular 18 (Richardson and others, 1995). Scour depths were calculated assuming an infinite depth of erosive material and a homogeneous particle-size distribution. The results of the scour analysis are presented in tables 1 and 2 and a graph of the scour depths is presented in figure 8 .

The 100-year, 500-year, and incipient roadway-overtopping discharges modelled resulted in unsubmerged orifice flow. Contraction scour at bridges with orifice flow is best estimated by use of the Chang pressure-flow scour equation (oral communication, J. Sterling Jones, October 4, 1996). Thus, contraction scour was computed by use of the Chang equation (Richardson and others, 1995, p. 145-146). Results of this analysis are presented in figure 8 and tables 1 and 2 .

Additional estimates of contraction scour also were computed by use of Laursen's clear-water scour equation (Richardson and others, 1995, p. 32, equation 20) and Umbrell's pressure-flow scour equation (Richardson and other, 1995, p. 144-146), and the results are presented in Appendix F. Furthermore, since the discharges resulted in unsubmerged orifice flow, contraction scour was computed by substituting alternative estimates for the depth of flow in the bridge at the downstream face in the Chang equation and Laursen's clear-water equation. Contraction scour results with respect to these substitutions also are provided in Appendix F.

Abutment scour for the right abutment was computed by use of the Froehlich equation (Richardson and others, 1995, p. 48, equation 28). Variables for the Froehlich equation include the Froude number of the flow approaching the embankments, the length of the embankment blocking flow, and the depth of flow approaching the embankment less any roadway overtopping.

Scour at the left abutment for all discharges was computed by use of the HIRE equation (Richardson and others, 1995, p. 49, equation 29) because the HIRE equation is recommended when the length to depth ratio of the embankment blocking flow exceeds 25 . The variables used by the HIRE abutment-scour equation are defined the same as those defined for the Froehlich abutment-scour equation. 


\section{Scour Results}

100-yr discharge 500-yr discharge

(Scour depths in feet)
Incipient overtopping discharge

Main channel

Live-bed scour

Clear-water scour

Depth to armoring

Left overbank

Right overbank

Local scour:

Abutment scour

Left abutment

Right abutment

Pier scour

Pier 1

Pier 2

Pier 3
13.6

$11.1-$
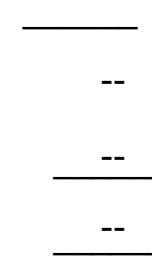

18.7

14.6-

6.9

12.4
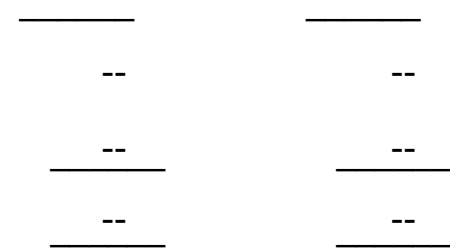

\section{Riprap Sizing}

\section{Abutments:}

\section{Left abutment}

\section{Right abutment}

Piers:

Pier 1

Pier 2

Incipient overtopping 100-yrdischarge 500-yrdischarge discharge

2.4 ( $D_{50}$ in feet)

$2.9 \quad 2.7$

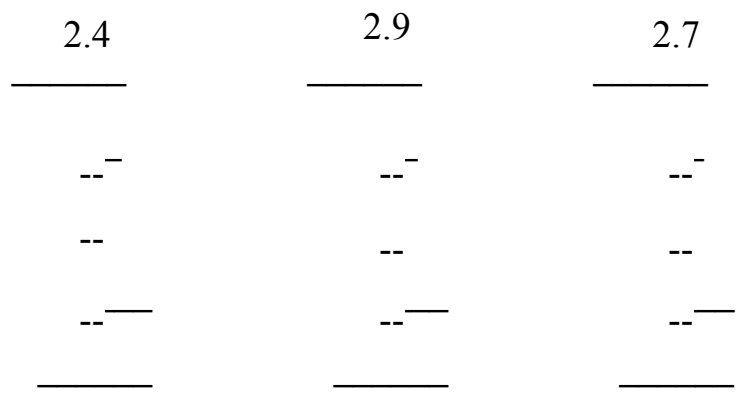




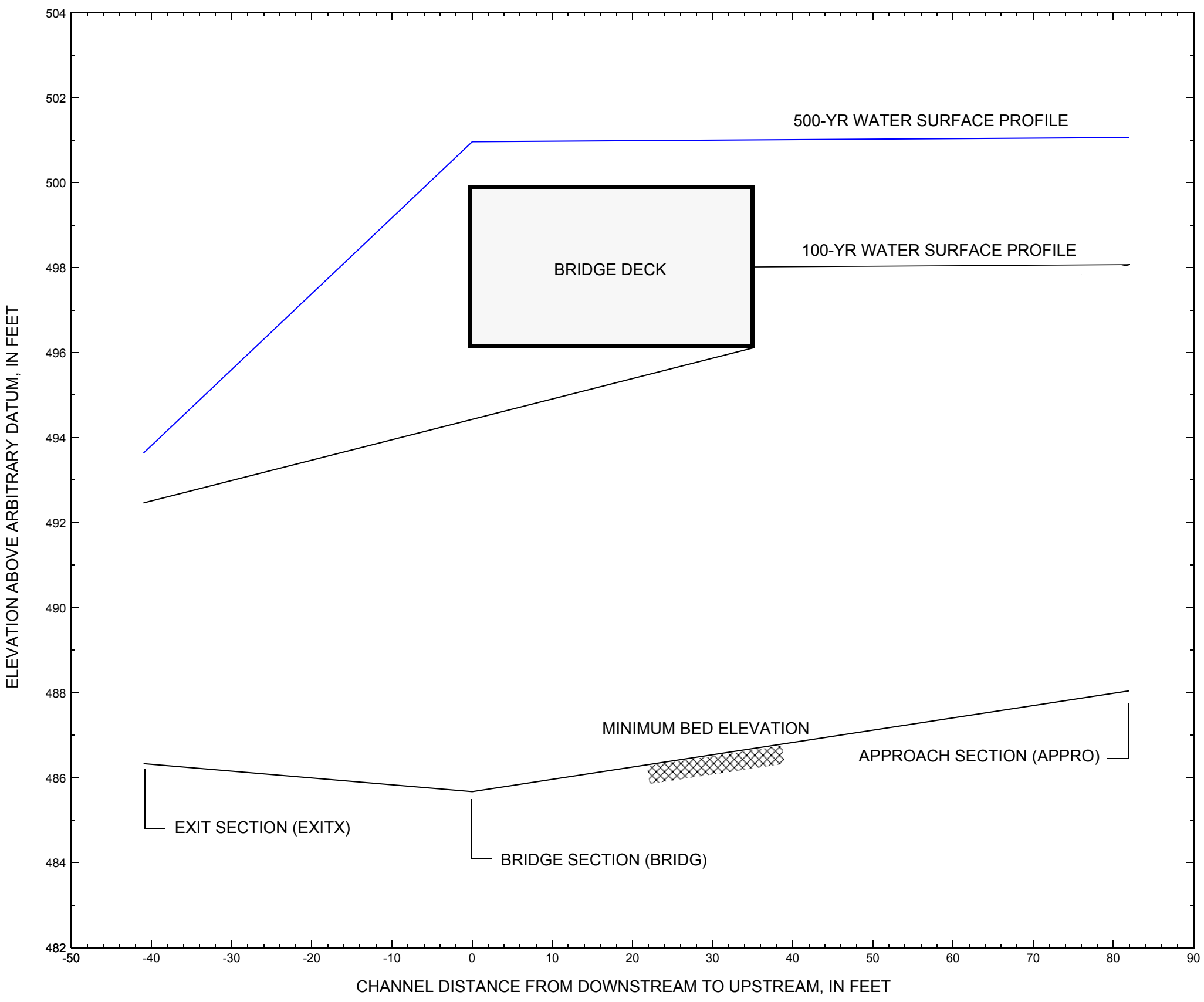

Figure 7. Water-surface profiles for the 100- and 500-yr discharges at structure ANDOVT00110041 on State Route 11, crossing the Middle Branch Williams River, Andover, Vermont. 


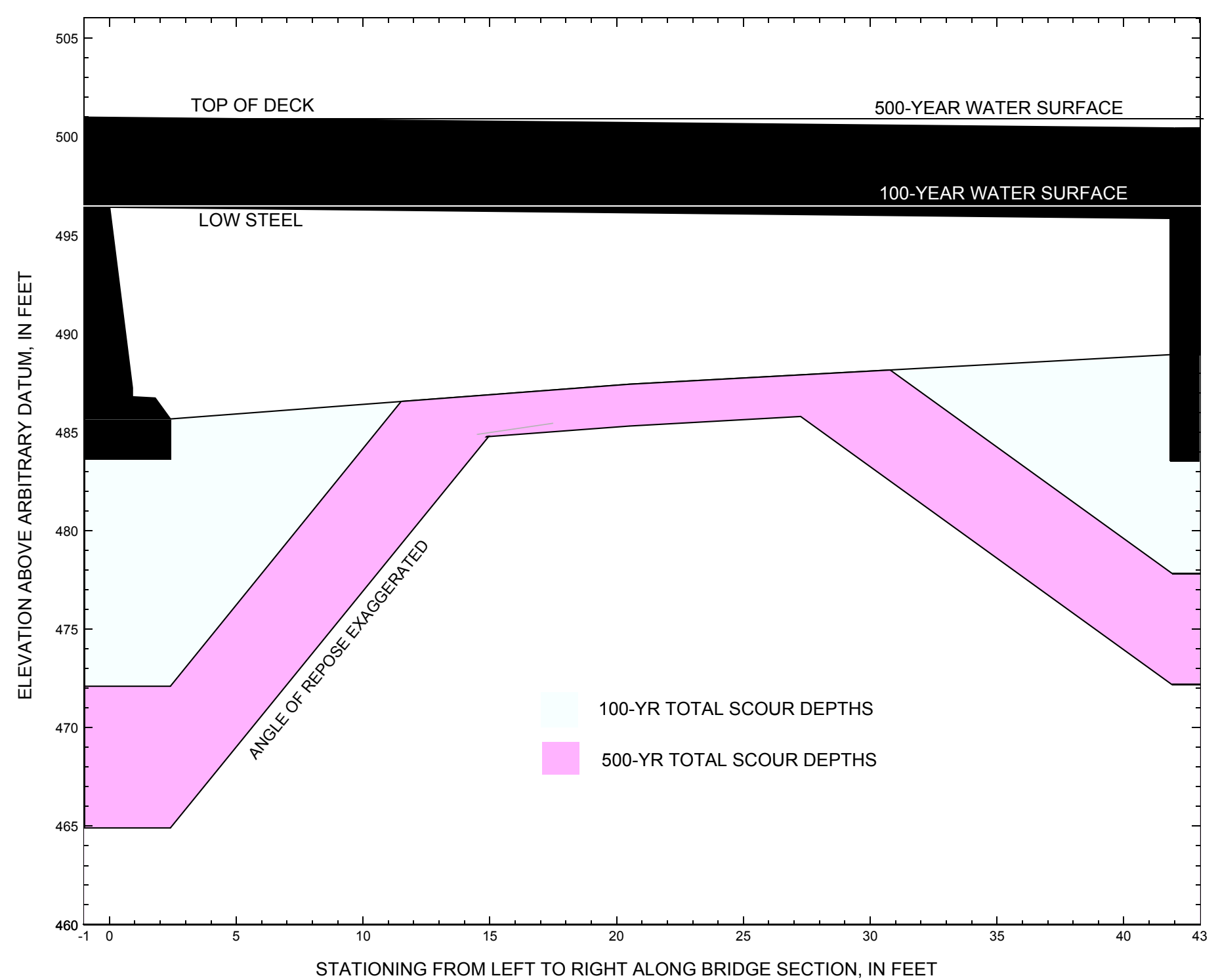

Figure 8. Scour elevations for the 100-yr and 500-yr discharges at structure ANDOVT00110041 on State Route 11, crossing the Middle Branch Williams River, Andover, Vermont. 
Table 1. Remaining footing/pile depth at abutments for the 100-year discharge at structure ANDOVT00110041 on State Route 11, crossing the Middle Branch Williams River, Andover, Vermont.

[VTAOT, Vermont Agency of Transportation; --,no data]

\begin{tabular}{|c|c|c|c|c|c|c|c|c|c|c|c|}
\hline Description & Station $^{1}$ & $\begin{array}{l}\text { VTAOT } \\
\text { minimum } \\
\text { bridge seat } \\
\text { elevation } \\
\text { (feet) }\end{array}$ & $\begin{array}{l}\text { Surveyed } \\
\text { minimum } \\
\text { low-chord } \\
\text { elevation } \\
\quad \text { (feet) }\end{array}$ & $\begin{array}{l}\text { Bottom of } \\
\text { footing } \\
\text { elevation } \\
\text { (feet) }\end{array}$ & $\begin{array}{c}\text { Channel } \\
\text { elevation at } \\
\text { abutment/ } \\
\text { pier }^{2} \\
\text { (feet) }\end{array}$ & $\begin{array}{l}\text { Contraction } \\
\text { scour depth } \\
\text { (feet) }\end{array}$ & $\begin{array}{l}\text { Abutment } \\
\text { scour } \\
\text { depth } \\
\text { (feet) }\end{array}$ & $\begin{array}{l}\text { Pier } \\
\text { scour } \\
\text { depth } \\
\text { (feet) }\end{array}$ & $\begin{array}{l}\text { Depth of } \\
\text { total scour } \\
\text { (feet) }\end{array}$ & $\begin{array}{c}\text { Elevation of } \\
\text { scour }^{2} \\
\text { (feet) }\end{array}$ & $\begin{array}{l}\text { Remaining } \\
\text { footing/pile } \\
\text { depth } \\
\text { (feet) }\end{array}$ \\
\hline \multicolumn{12}{|c|}{100 -yr. discharge is 3,270 cubic-feet per second } \\
\hline Left abutment & 0.0 & 1065.8 & 496.4 & 483.5 & 485.7 & 0.0 & 13.6 & -- & 13.6 & 472.1 & -11.4 \\
\hline Right abutment & 42.0 & 1065.3 & 495.9 & 483.5 & 488.9 & 0.0 & 11.1 & -- & 11.1 & 477.8 & -5.7 \\
\hline
\end{tabular}

1.Measured along the face of the most constricting side of the bridge.

2.Arbitrary datum for this study.

Table 2. Remaining footing/pile depth at abutments for the 500-year discharge at structure ANDOVT00110041 on State Route 11, crossing the Middle Branch Williams River, Andover, Vermont.

[VTAOT, Vermont Agency of Transportation; --, no data]

\begin{tabular}{|c|c|c|c|c|c|c|c|c|c|c|c|}
\hline Description & Station $^{1}$ & $\begin{array}{c}\text { VTAOT } \\
\text { minimum } \\
\text { bridge seat } \\
\text { elevation } \\
\text { (feet) }\end{array}$ & $\begin{array}{c}\text { Surveyed } \\
\text { minimum } \\
\text { low-chord } \\
\text { elevation } \\
\text { (feet) }\end{array}$ & $\begin{array}{l}\text { Bottom of } \\
\text { footing } \\
\text { elevation } \\
\text { (feet) }\end{array}$ & $\begin{array}{c}\text { Channel } \\
\text { elevation at } \\
\text { abutment/ } \\
\text { pier }^{2} \\
\text { (feet) }\end{array}$ & $\begin{array}{l}\text { Contraction } \\
\text { scour depth } \\
\text { (feet) }\end{array}$ & $\begin{array}{l}\text { Abutment } \\
\text { scour } \\
\text { depth } \\
\text { (feet) }\end{array}$ & $\begin{array}{l}\text { Pier } \\
\text { scour } \\
\text { depth } \\
\text { (feet) }\end{array}$ & $\begin{array}{l}\text { Depth of } \\
\text { total scour } \\
\text { (feet) }\end{array}$ & $\begin{array}{c}\text { Elevation of } \\
\text { scour }^{2} \\
\text { (feet) }\end{array}$ & $\begin{array}{c}\text { Remaining } \\
\text { footing/pile } \\
\text { depth } \\
\text { (feet) }\end{array}$ \\
\hline \multicolumn{12}{|c|}{500 -yr. discharge is 4,810 cubic-feet per second } \\
\hline Left abutment & 0.0 & 1065.8 & 496.4 & 483.5 & 485.7 & 2.1 & 18.7 & -- & 20.8 & 464.9 & -18.6 \\
\hline Right abutment & 42.0 & 1065.3 & 495.9 & 483.5 & 488.9 & 2.1 & 14.6 & -- & 16.7 & 472.2 & -11.3 \\
\hline
\end{tabular}

1.Measured along the face of the most constricting side of the bridge.

2.Arbitrary datum for this study. 


\section{SELECTED REFERENCES}

Arcement, G.J., Jr., and Schneider, V.R., 1989, Guide for selecting Manning's roughness coefficients for natural channels and flood plains: U.S. Geological Survey Water-Supply Paper 2339, 38 p.

Barnes, H.H., Jr., 1967, Roughness characteristics of natural channels: U.S. Geological Survey Water-Supply Paper 1849, 213 p.

Benson, M. A., 1962, Factors Influencing the Occurrence of Floods in a Humid Region of Diverse Terrain: U.S. Geological Survey Water-Supply Paper 1580-B, $64 \mathrm{p}$.

Brown, S.A. and Clyde, E.S., 1989, Design of riprap revetment: Federal Highway Administration Hydraulic Engineering Circular No. 11, Publication FHWA-IP-89-016, 156 p.

Federal Highway Administration, 1983, Runoff estimates for small watersheds and development of sound design: Federal Highway Administration Report FHWA-RD-77-158.

Federal Highway Administration, 1993, Stream Stability and Scour at Highway Bridges: Participant Workbook: Federal Highway Administration Report FHWA-HI-91-011.

Federal Emergency Management Agency, 1982, Flood Insurance Study, Town of Chester, Windsor County, Vermont: Washington, D.C., February 1982.

Froehlich, D.C., 1989, Local scour at bridge abutments in Ports, M.A., ed., Hydraulic Engineering--Proceedings of the 1989 National Conference on Hydraulic Engineering: New York, American Society of Civil Engineers, p. 13-18.

Hayes, D.C.,1993, Site selection and collection of bridge-scour data in Delaware, Maryland, and Virginia: U.S. Geological Survey Water-Resources Investigation Report 93-4017, 23 p.

Interagency Advisory Committee on Water Data, 1982, Guidelines for determining flood flow frequency: U.S. Geological Survey, Bulletin 17B of the Hydrology Subcommittee, 190 p.

Johnson, C.G. and Tasker, G.D.,1974, Progress report on flood magnitude and frequency of Vermont streams: U.S. Geological Survey Open-File Report 74-130, $37 \mathrm{p}$.

Lagasse, P.F., Schall, J.D., Johnson, F., Richardson, E.V., Chang, F., 1995, Stream Stability at Highway Structures: Federal Highway Administration Hydraulic Engineering Circular No. 20, Publication FHWA-IP-90-014, 144 p.

Laursen, E.M., 1960, Scour at bridge crossings: Journal of the Hydraulics Division, American Society of Civil Engineers, v. 86, no. HY2, p. 39-53.

Potter, W. D., 1957a, Peak rates of runoff in the Adirondack, White Mountains, and Maine woods area, Bureau of Public Roads

Potter, W. D., 1957b, Peak rates of runoff in the New England Hill and Lowland area, Bureau of Public Roads

Richardson, E.V. and Davis, S.R., 1995, Evaluating scour at bridges: Federal Highway Administration Hydraulic Engineering Circular No. 18, Publication FHWA-IP-90-017, 204 p.

Richardson, E.V., Simons, D.B., and Julien, P.Y., 1990, Highways in the river environment: Federal Highway Administration Publication FHWAHI-90-016.

Ritter, D.F., 1984, Process Geomorphology: W.C. Brown Co., Debuque, Iowa, 603 p.

Shearman, J.O., 1990, User's manual for WSPRO--a computer model for water surface profile computations: Federal Highway Administration Publication FHWA-IP-89-027, 187 p.

Shearman, J.O., Kirby, W.H., Schneider, V.R., and Flippo, H.N., 1986, Bridge waterways analysis model; research report: Federal Highway Administration Publication FHWA-RD-86-108, 112 p.

Talbot, A.N., 1887, The determination of water-way for bridges and culverts.

U.S. Department of Transportation, 1993, Stream stability and scour at highway bridges, Participant Workbook: Federal Highway Administration Publication FHWA HI-91-011.

U.S. Geological Survey, 1971, Andover, Vermont 7.5 Minute Series quadrangle map: U.S. Geological Survey Topographic Maps, Scale 1:24,000. 


\section{APPENDIX A: \\ WSPRO INPUT FILE}




\section{WSPRO INPUT FILE}

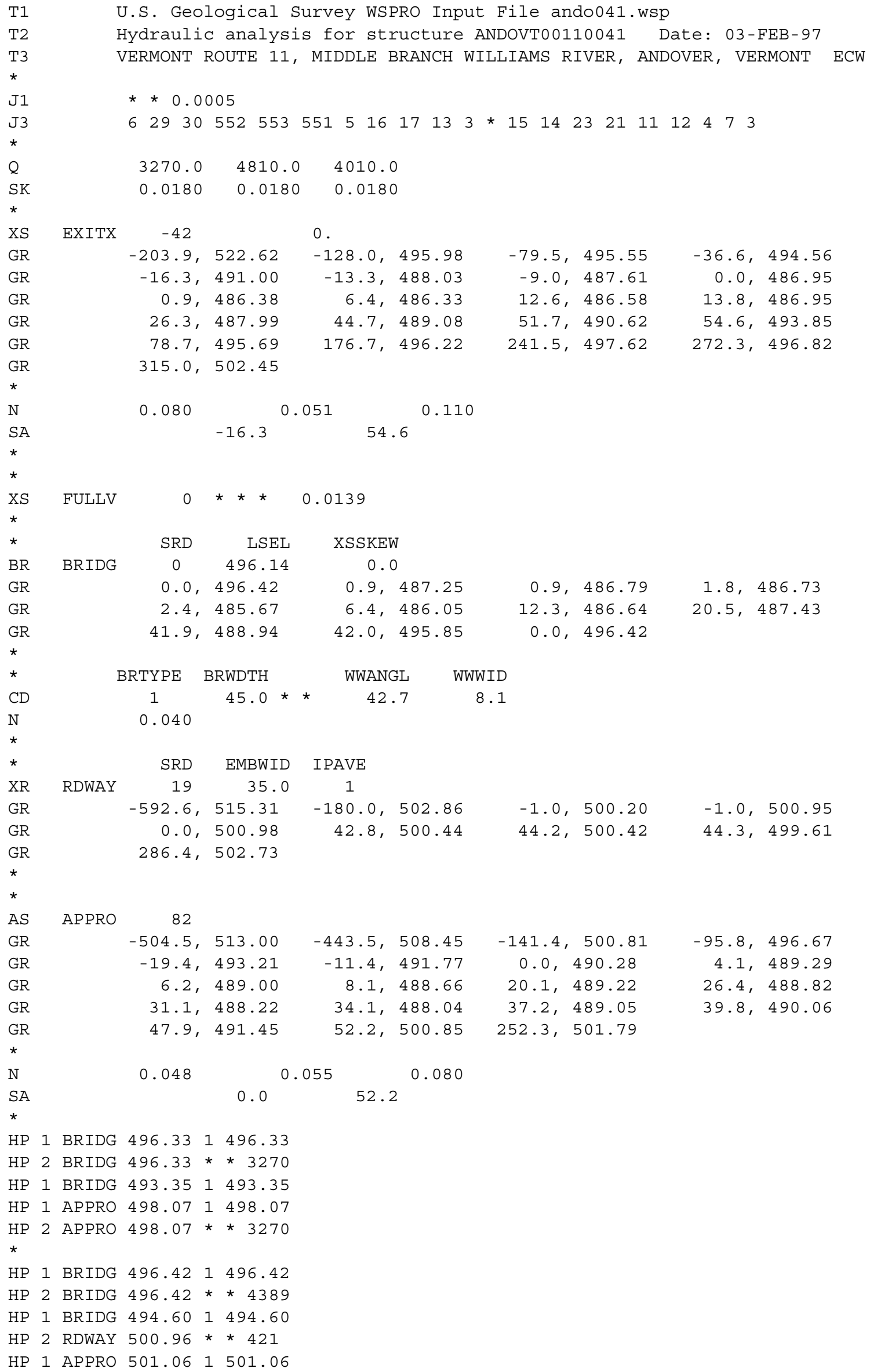




\section{APPENDIX B: \\ WSPRO OUTPUT FILE}


WSPRO OUTPUT FILE

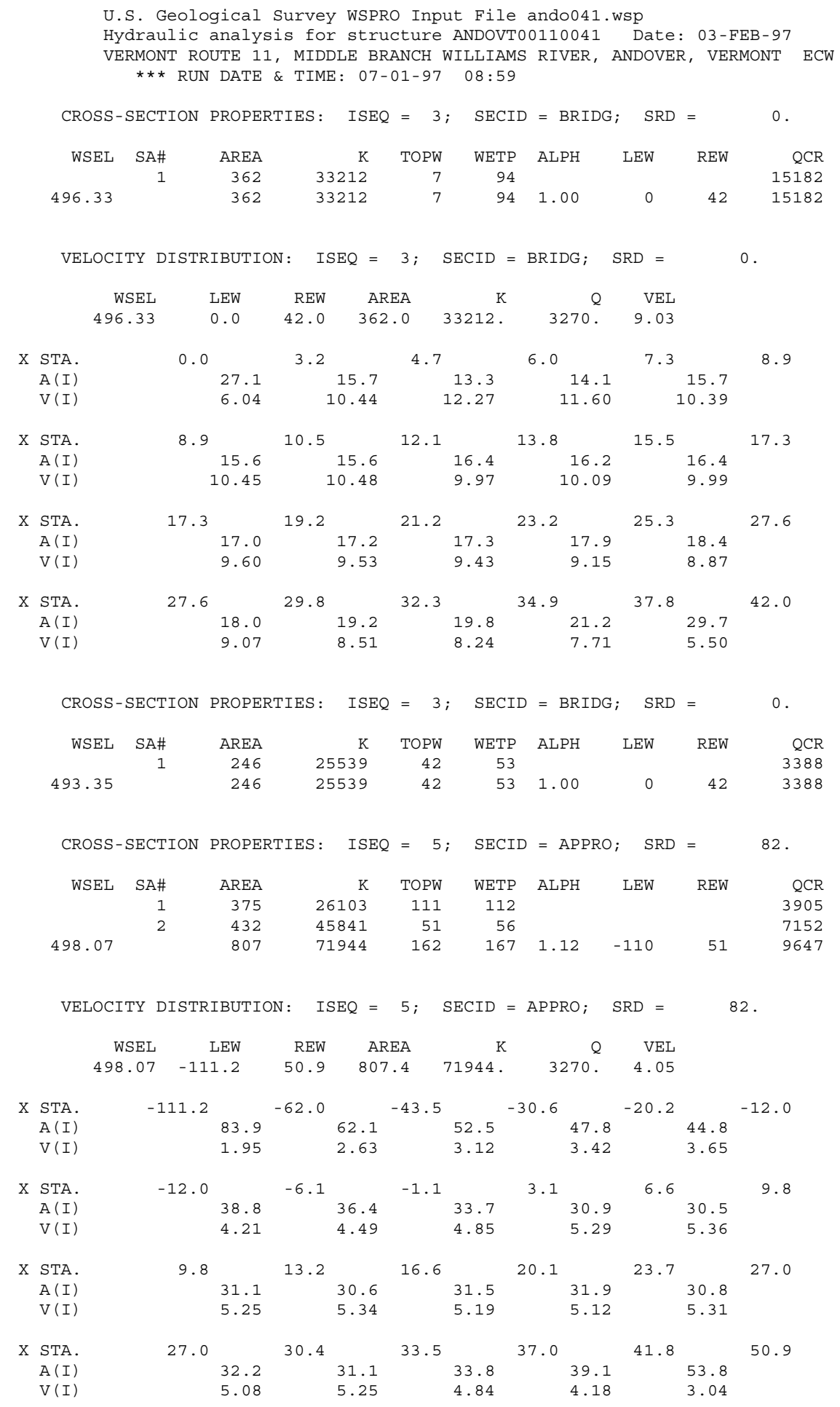


WSPRO OUTPUT FILE (continued)

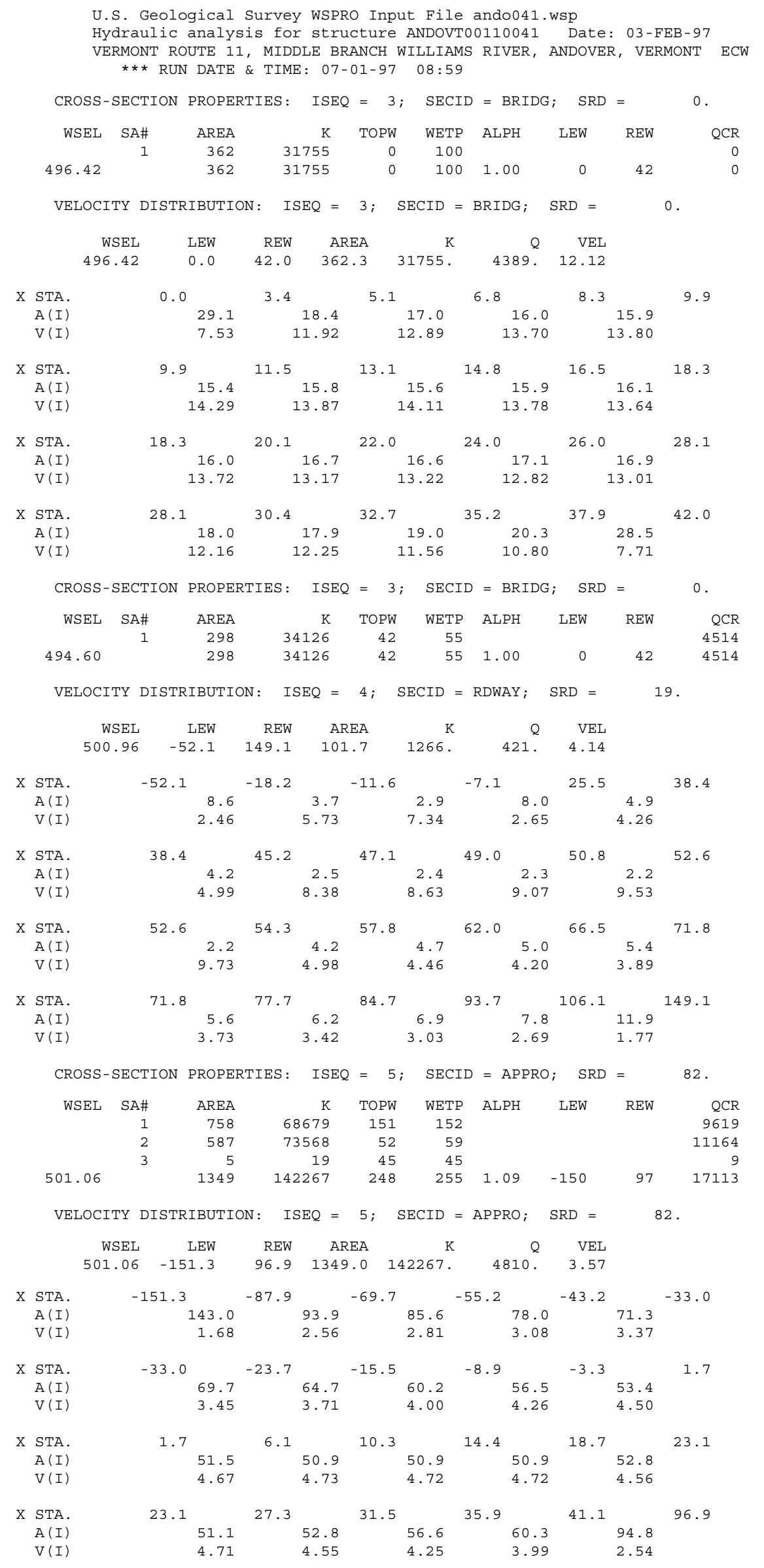


WSPRO OUTPUT FILE (continued)

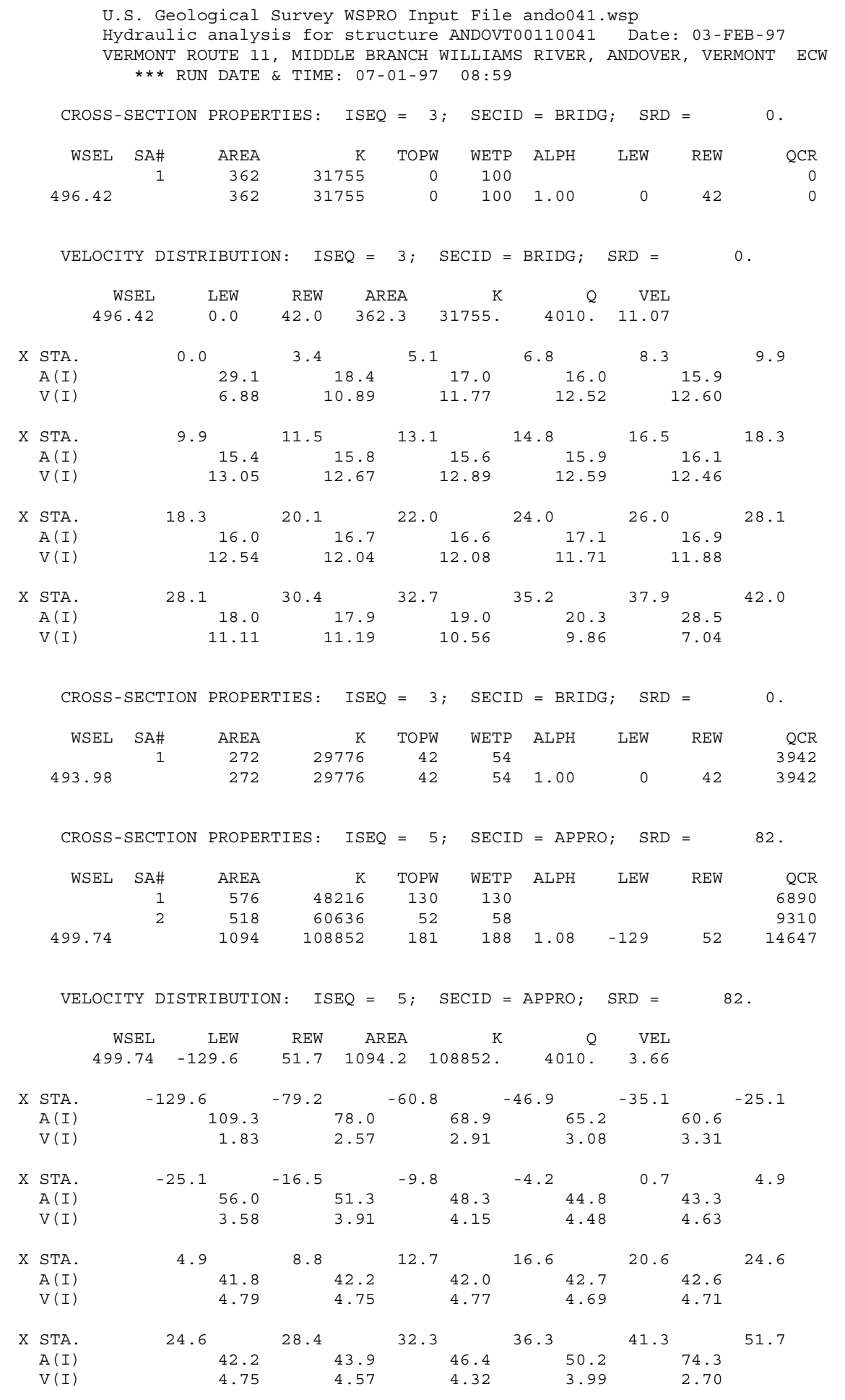


WSPRO OUTPUT FILE (continued)

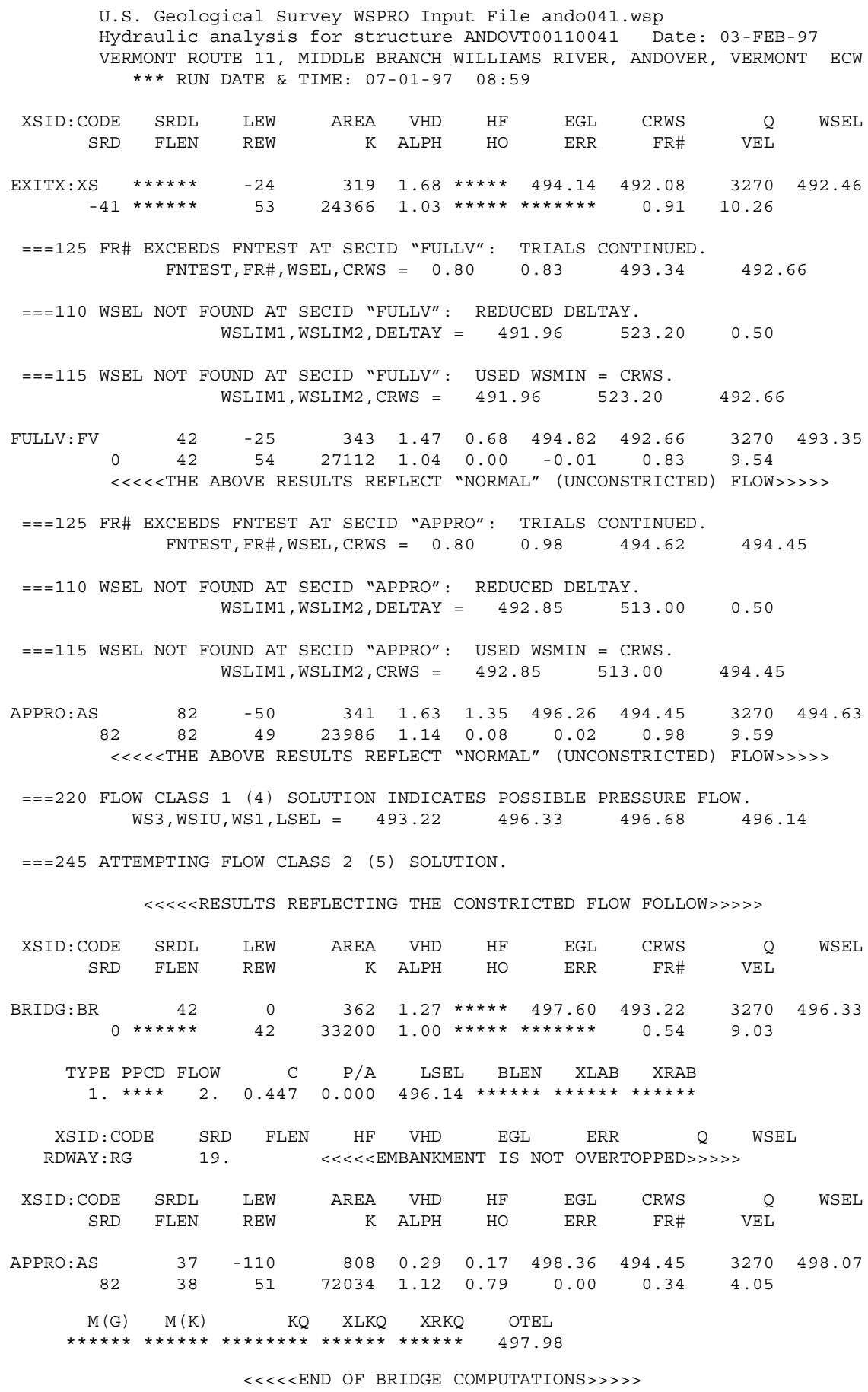

FIRST USER DEFINED TABLE.

\begin{tabular}{|c|c|c|c|c|c|c|c|c|}
\hline XSID : CODE & SRD & LEW & REW & 0 & $\mathrm{~K}$ & AREA & VEL & WSEL \\
\hline EXITX:XS & -42 . & -25 & 53. & 3270 . & 24366 . & 319. & 10.26 & 492.46 \\
\hline FULLV : FV & 0 . & -26 & 54. & 3270 . & 27112 . & 343 . & 9.54 & 493.35 \\
\hline BRIDG : BR & 0 . & 0. & 42 . & 3270 . & 33200 . & 362. & 9.03 & 496.33 \\
\hline RDWAY : RG & \multicolumn{3}{|c|}{ 19. $* * * * * * * * * * * * * *$} & \multicolumn{3}{|c|}{$0 . * * \star * * * * * * \star * * \star * * * * * *$} & \multicolumn{2}{|c|}{$1.00 * * * * * * * *$} \\
\hline APPRO : AS & 82 . & -111. & 51. & 3270 . & 72034 & 808 & 4.05 & 498.07 \\
\hline XSID & LKQ & XRKQ & & & & & & \\
\hline
\end{tabular}

SECOND USER DEFINED TABLE.

\begin{tabular}{|c|c|c|c|c|c|c|c|c|c|}
\hline XSID : CODE & CRWS & FR\# & YMIN & YMAX & $\mathrm{HF}$ & $\mathrm{HO}$ & VHD & EGL & WSEL \\
\hline EXITX:XS & 492.08 & .91 & 86.33 & 22.62 * & $* \star \star *$ & $\star \star \star \star \star *$ & 1.68 & 94.14 & 92.46 \\
\hline FULLV : FV & 492.66 & 0.83 & 486.91 & 523.20 & 0.68 & 0.00 & 1.47 & 494.82 & 493.35 \\
\hline BRIDG : BR & 493.22 & 0.54 & 485.67 & 496.42 * & 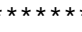 & $\star \star \star \star \star$ & 1.27 & 497.60 & 496.33 \\
\hline DWAY : RG & 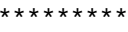 & $\star \star \star \star \star *$ & 499.61 & $515.31 *$ & $* * * * *$ & $* * \star * *$ & 0.12 & $500.45^{*}$ & 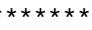 \\
\hline PPRO : AS & 494.45 & 0.34 & 488.04 & 513.00 & 0.17 & 0.79 & 0.29 & 498.36 & 498.07 \\
\hline
\end{tabular}


WSPRO OUTPUT FILE (continued)

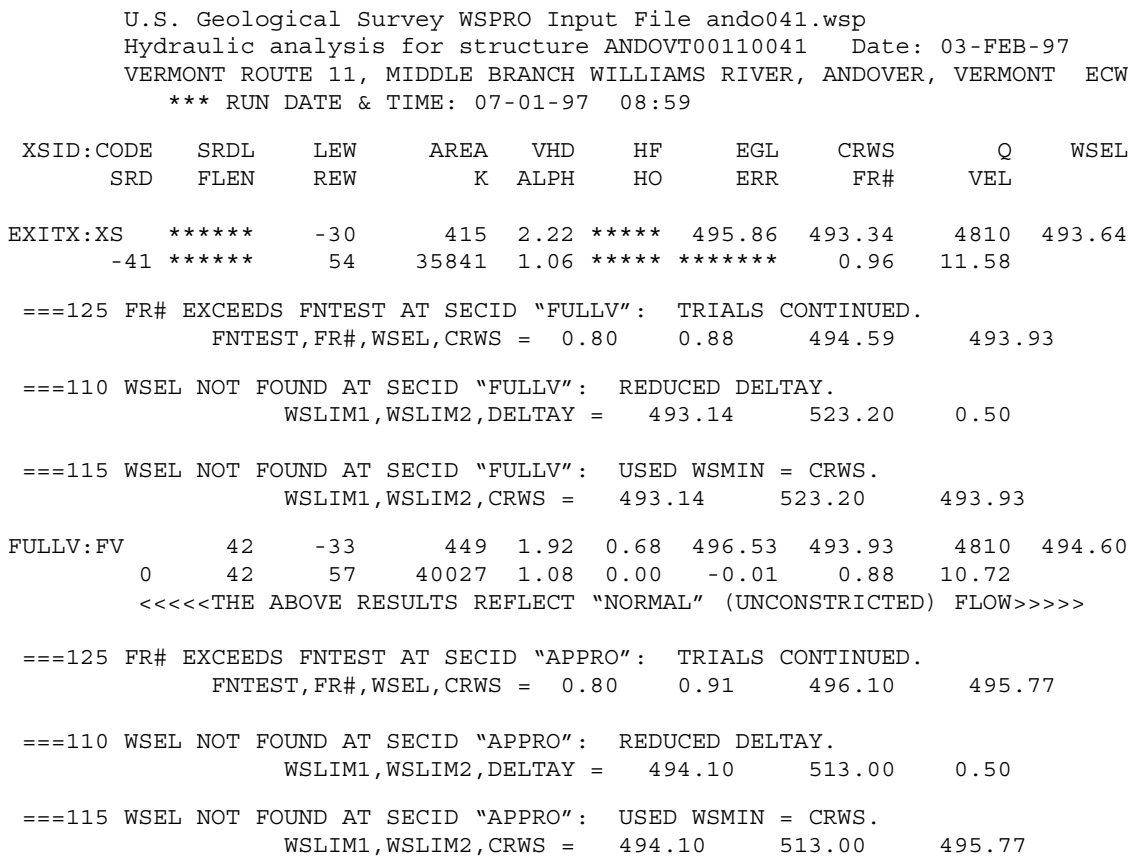

\begin{tabular}{|c|c|c|c|c|c|c|c|c|c|c|}
\hline XSID: CODE & SRD & LEW & REW & $Q$ & $\mathrm{~K}$ & \multicolumn{2}{|c|}{ AREA } & VEL & \multicolumn{2}{|c|}{ WSEL } \\
\hline EXITX : XS & -42 . & -31 & 54. & 4810. & 5841. & \multicolumn{2}{|c|}{415 . } & 11.58 & \multicolumn{2}{|c|}{493.64} \\
\hline FULLV : FV & 0 . & -34. & 57. & 4810. & 027. & \multicolumn{2}{|c|}{449 . } & 10.72 & \multicolumn{2}{|c|}{494.60} \\
\hline BRIDG : BR & 0. & 0 . & 42 . & 4389. & 1755. & \multicolumn{2}{|c|}{362 . } & 12.11 & \multicolumn{2}{|c|}{496.42} \\
\hline RDWAY : RG & \multicolumn{2}{|c|}{$19 . * \star \star * \star * \star *$} & 91. & \multicolumn{4}{|c|}{$421 . * * * * * * * * * * * * * * * * * *$} & 1.00 & \multicolumn{2}{|c|}{500.96} \\
\hline APPRO : AS & 82 . & -151. & 98. & 4810. & 2333. & \multicolumn{2}{|c|}{1350.} & 3.56 & \multirow{2}{*}{\multicolumn{2}{|c|}{501.06}} \\
\hline XSID : CODE & XLKQ & $\mathrm{XRKQ}$ & $\mathrm{KQ}$ & & & & & & & \\
\hline \multicolumn{11}{|c|}{ 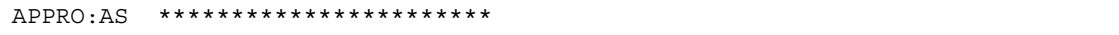 } \\
\hline OND USER I & & BLE. & & & & & & & & \\
\hline XSID : CODE & CRWS & FR\# & YMIN & YMAX & $\mathrm{HF}$ & HO & VHD & $\mathrm{EC}$ & & WS \\
\hline EXITX:XS & 493.34 & 0.96 & 486.33 & $522.62 *$ & $* * * * * *$ & $\star \star \star \star \star *$ & 2.22 & 495.8 & & 493. \\
\hline FULLV : FV & 493.93 & 0.88 & 486.91 & 523.20 & 0.68 & 0.00 & 1.92 & 496.5 & & 494.6 \\
\hline BRIDG : BR & 494.46 & 0.73 & 485.67 & $496.42 *$ & $\star \star \star \star \star * *$ & $\star \star \star * * *$ & 2.28 & 498.7 & & 496.4 \\
\hline RDWAY : RG & $\star \star \star \star * \star * \star * * *$ & $\star \star \star \star \star * *$ & 499.61 & 515.31 & $0.05 *$ & $\star * \star * *$ & 0.21 & 501.2 & & 500. \\
\hline APPRO: AS & 95.77 & 28 & 88.04 & 00 & 0.18 & 78 & 0.21 & 501.2 & & 501 \\
\hline
\end{tabular}


WSPRO OUTPUT FILE (continued)

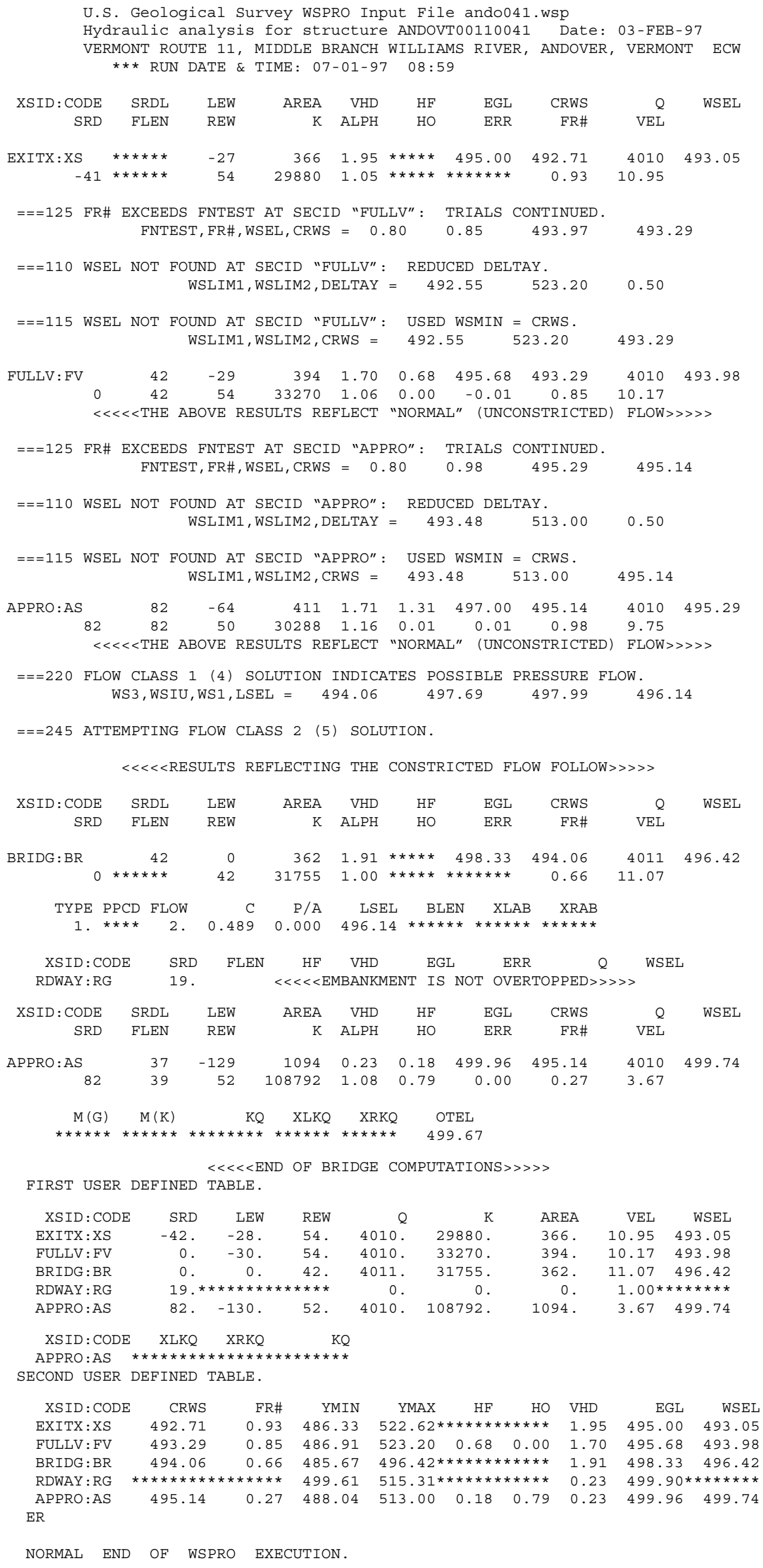

\begin{tabular}{|c|c|c|c|c|c|c|c|c|c|}
\hline XSID : CODE & CRWS & FR\# & YMIN & YMAX & $\mathrm{HF}$ & $\mathrm{HO}$ & VHD & EGL & WSEL \\
\hline EXITX:XS & 492.71 & 0.93 & 486.33 & $522.62 *$ & $\star \star \star \star \star * *$ & $\star \star \star \star \star \star *$ & 1.95 & 495.00 & 493.05 \\
\hline FULLV : FV & 493.29 & 0.85 & 486.91 & 523.20 & 0.68 & 0.00 & 1.70 & 495.68 & 493.98 \\
\hline BRIDG : BR & 494.06 & 0.66 & 485.67 & 496.42 * & $\star \star \star \star \star * *$ & $\star \star \star \star \star *$ & 1.91 & 498.33 & 496.42 \\
\hline RDWAY : RG & 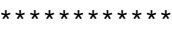 & $\star \star \star \star *$ & 499.61 & $515.31 *$ & $\star * \star * \star * *$ & $\star \star \star \star \star *$ & 0.23 & $499.90 * *$ & 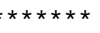 \\
\hline APPRO : AS & 495.14 & 0.27 & 488.04 & 513.00 & 0.18 & 0.79 & 0.23 & 499.96 & 499.74 \\
\hline 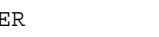 & & & & & & & & & \\
\hline
\end{tabular}




\section{APPENDIX C:}

\section{BED-MATERIAL PARTICLE-SIZE DISTRIBUTION}




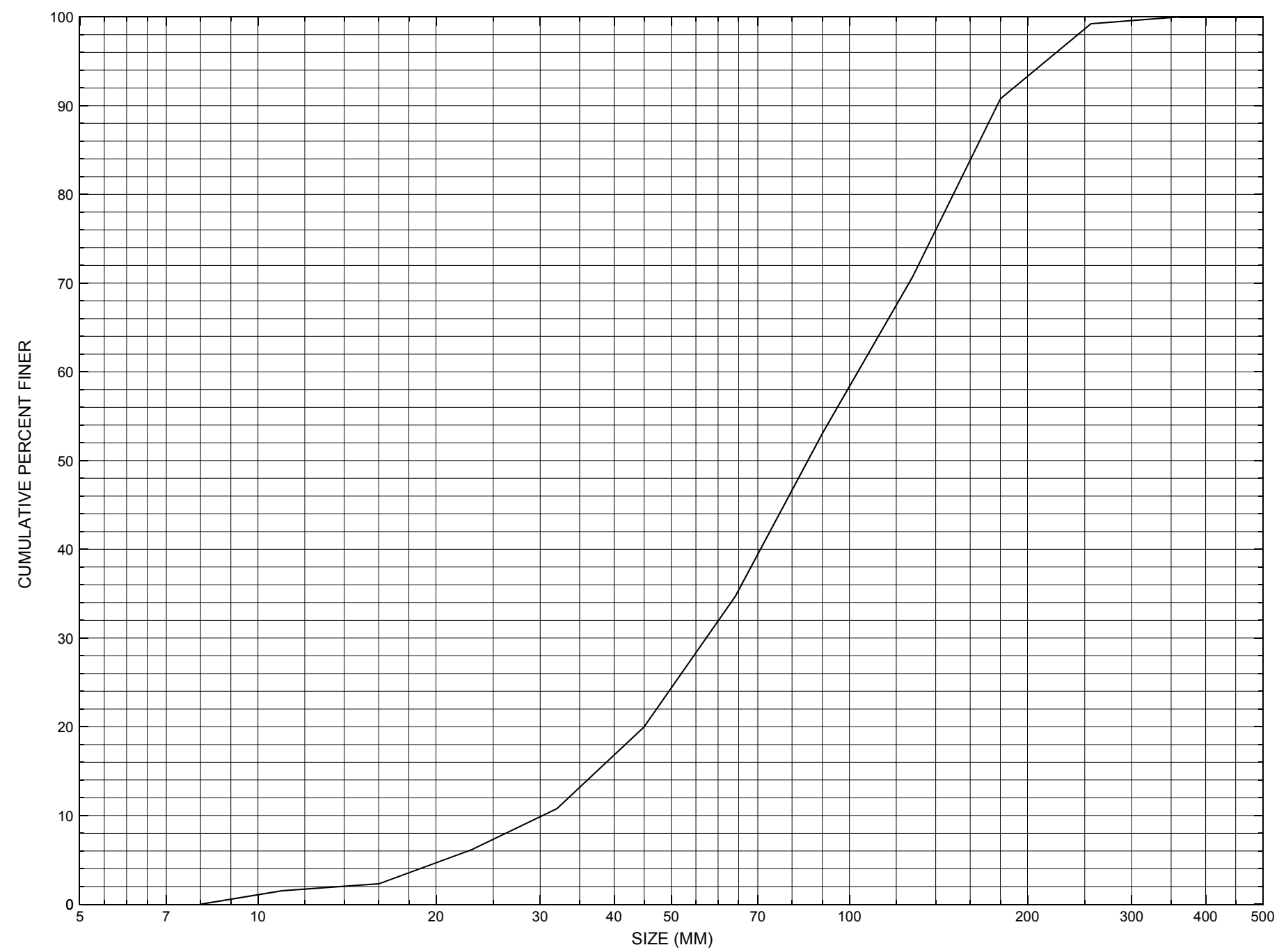

Appendix C. Bed material particle-size distribution for a pebble count in the channel approach of structure ANDOVT00110041, in Andover, Vermont. 


\section{APPENDIX D: \\ HISTORICAL DATA FORM}




\section{Structure Number ANDOVT00110041}

\section{General Location Descriptive}

Data collected by (First Initial, Full last name) $\underline{\text { M. IVANOFF }}$

Date $(M M / D D / Y Y) \_\mathbf{0 3} / \underline{29} / \underline{95}$

Highway District Number (I - 2; nn) $\mathbf{0 2}$

Town (FIPS place code; I - 4; nnnnn) $\mathbf{0 1 3 0 0}$

Waterway (I - 6) MIDDLE BR WILLIAMS RIVER

Route Number VT 11

Topographic Map Andover

Latitude (I - 16; nnnn.n) $\mathbf{4 3 1 5 6}$
County (FIPS county code; I - 3; nnn)

Mile marker (I - 11; nnn.nnn) $\mathbf{0 0 2 6 7 0}$

Road Name (I - 7): -

Vicinity (I - 9) 4.0 MI E JCT VT 121

Hydrologic Unit Code: $\underline{\mathbf{0 1 0 8 0 1 0 7}}$

Longitude (i - 17; nnnnn.n) $\mathbf{7 2 4 2 1}$

\section{Select Federal Inventory Codes}

FHWA Structure Number $(I-8) \underline{\mathbf{2 0 0 0 1 6 0 0 4 1 1 4 0 1}}$

Maintenance responsibility $(I-21 ; n n) \_$01_ Maximum span length $(I-48$; $n n n n) \underline{\mathbf{0 0 4 4}}$

Year built (I - 27; YYYY) 1927

Structure length (I - 49; nnnnnn) $\underline{000046}$

Average daily traffic, ADT (I - 29; nnnnnn) $\underline{002736}$

Deck Width (I- 52; nn.n) $\mathbf{3 5 0}$

Year of ADT (I - 30; YY) $\mathbf{9 2}$

Channel \& Protection $(I-61 ; n)$

Opening skew to Roadway $(I-34 ; n n) \quad \mathbf{0 0}$

Waterway adequacy $(I-71 ; n) \underline{\mathbf{3}}$

Operational status $(I-41 ; X) \quad \mathbf{A}$

Underwater Inspection Frequency $(I-92 B ; X Y Y) \_\mathbf{N}$

Structure type (I - 43; nnn) 104

Year Reconstructed (I - 106) $\mathbf{0 0 0 0}$

Approach span structure type (I - 44; nnn) $\mathbf{0 0 0}$ Clear span (nnn.n ft)

Number of spans (I - 45; nnn) $\underline{\mathbf{0 0 1}}$

Vertical clearance from streambed (nnn.n ft) $\underline{\mathbf{8 . 0}}$

Number of approach spans (I - 46; nnnn) $\mathbf{0 0 0 0}$

Waterway of full opening (nnn.n $\left.\mathrm{ft}^{2}\right)$

Comments:

The structural inspection report of 11/10/93 indicates the structure is a concrete T-beam type bridge with an asphault roadway surface. The deck was extensively rehabilitated in the summer of 1992. Both abutment walls are older sections of concrete walls with newer ends. Along the bottom of the original concrete wall of the left abutment there is some deep erosion of the concrete. Erosion extends up to 9 inches behind the front face of the abutment wall. The footing is in view along the older portion, and for the most part appears to be quite sound. It does have some deep erosion. The newer section of the footing is exposed along the downstream end of the left abutment, but there is no apparent (Continued, page 33) 


\section{Bridge Hydrologic Data}

Is there hydrologic data available? $\underline{\mathbf{N}}$ if No, type ctrl-n $h \quad$ VTAOT Drainage area $\left(m i^{2}\right)$ : -

Terrain character:

Stream character \& type: -

Streambed material:

Discharge Data (cfs):

$$
\begin{aligned}
& Q_{2.33}- \\
& Q_{50}-
\end{aligned}
$$

Record flood date $(M M / D D / Y Y)$ :

Estimated Discharge (cfs): Ice conditions (Heavy, Moderate, Light) : -

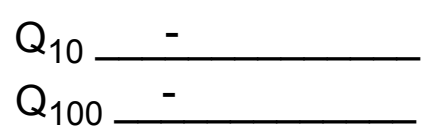

$$
\begin{aligned}
& Q_{25}- \\
& Q_{500}-
\end{aligned}
$$

Water surface elevation $(f t):-$

The stage increases to maximum highwater elevation (Rapidly, Not rapidly):

The stream response is (Flashy, Not flashy):

Describe any significant site conditions upstream or downstream that may influence the stream's stage: -

Watershed storage area (in percent): _ _ \%

The watershed storage area is: - (1-mainly at the headwaters; 2- uniformly distributed; 3-immediatly upstream oi the site)

Water Surface Elevation Estimates for Existing Structure:

\begin{tabular}{|l|l|l|l|l|l|}
\hline Peak discharge frequency & $Q_{2.33}$ & $Q_{10}$ & $Q_{25}$ & $Q_{50}$ & $Q_{100}$ \\
Water surface elevation (ft)) & - & - & - & - & - \\
Velocity (ft/sec) & - & - & - & - & - \\
\hline
\end{tabular}

Long term stream bed changes: -

Is the roadway overtopped below the $\mathrm{Q}_{100}$ ? (Yes, No, Unknown): $\mathbf{U}$ Frequency: Relief Elevation (ft): Discharge over roadway at $Q_{100}\left(f^{3} / \mathrm{sec}\right)$ :

Are there other structures nearby? (Yes, No, Unknown): $\underline{\mathbf{U}}$ Upstream distance (miles): Town: If No or Unknown, type ctrl-n os Highway No. : Structure No. : Year Built:

Clear span (ft): Clear Height $(f t)$ : Full Waterway $\left(f^{2}\right)$ : 
Downstream distance (miles): Town: Year Built:

Highway No. : Structure No. : Structure Type:

Clear span (ft): Clear Height $(f t)$ : Full Waterway $\left(f t^{2}\right)$ :

Comments:

undermining. There is a very small area where the top of the footing is exposed on the newer portion at the upstream end of the right abutment. All four wingwalls are in new condition. The waterway has a slight turn through the structure. The streambed consists of stone and boulders. There is a cobble bar roughly 100 feet upstream.

\section{USGS Watershed Data}

Watershed Hydrographic Data

Drainage area (DA) 12.07

Watershed storage (ST)

Bridge site elevation $\mathbf{0}$ $\mathrm{mi}^{2}$ 1088

Main channel length 6.05 $10 \%$ channel length elevation 1140

Main channel slope (S) 186.93 $\mathrm{ft} / \mathrm{mi}$ $\%$ $\mathrm{mi}$

Lake and pond area

0 $\mathrm{mi}^{2}$ Headwater elevation 2894 $\mathrm{ft}$ $\mathrm{ft} \quad 85 \%$ channel length elevation 1988 $\mathrm{ft}$

Watershed Precipitation Data

Average site precipitation in Average headwater precipitation in

Maximum 2yr-24hr precipitation event $(124,2)$ in

Average seasonal snowfall (Sn) $\mathrm{ft}$ 


\section{Bridge Plan Data}

Are plans available? $\mathbf{Y}$ If no, type ctrl-n pl Date issued for construction (MM/YYYY): $\underline{\mathbf{0 3}}$ / 1962 Project Number MA259/25.03M/1960

Minimum channel bed elevation: 1057.2

Low superstructure elevation: USLAB $\underline{\mathbf{1 0 6 6 . 1 0}}$ DSLAB $\underline{1065.83}$ USRAB $\underline{\mathbf{1 0 6 5 . 5 4}}$ DSRAB $\underline{\mathbf{1 0 6 5 . 2 7}}$ Benchmark location description:

BM\#38: spot on the upstream right wingwall, elevation 1068.69 transferred, now probably closer to 1068.88.

Reference Point (MSL, Arbitrary, Other): Arbitrary Datum (NAD27, NAD83, Other): Arbitrary Foundation Type: 1 (1-Spreadfooting; 2-Pile; 3- Gravity; 4-Unknown)

If 1: Footing Thickness $\mathbf{2 . 0} \quad$ Footing bottom elevation: $\underline{\mathbf{1 0 5 3 . 2}}$

If 2: Pile Type:___ (1-Wood; 2-Steel or metal; 3-Concrete) Approximate pile driven length:

If 3: Footing bottom elevation:

Is boring information available? $\mathbf{N}$ If no, type ctrl- $n$ bi Number of borings taken: _-

Foundation Material Type: $\mathbf{3}$ (1-regolith, 2-bedrock, 3-unknown)

Briefly describe material at foundation bottom elevation or around piles:

NO FOUNDATION MATERIAL INFORMATION.

Comments:

Plans are for bridge widening. The abutments were lengthened and footings set 2.3 feet lower than the bottom of the original footing set at 1055.5, which still remains for the middle 19 feet of the abutment walls. Other elevation points: 1 . on the streamward edge of the upstream right wingwall on top of the concrete where the concrete slope declines, elevation $1068.88 ; 2$. point at the same location as described above except on the upstream left wingwall, elevation 1069.44. 


\section{Cross-sectional Data}

Is cross-sectional data available? $\underline{\mathbf{Y}}$ If no, type ctrl-n xs

Source (FEMA, VTAOT, Other)? VTAOT

Comments: Several cross sections are available on the plans and may be retrieved when needed.

\begin{tabular}{|l|l|l|l|l|l|l|l|l|l|l|l|}
\hline Station & & & & & & & & & & & \\
\hline Feature & & & & & & & & & & & \\
\hline $\begin{array}{l}\text { Low cord } \\
\text { elevation }\end{array}$ & & & & & & & & & & & \\
\hline $\begin{array}{l}\text { Bed } \\
\text { elevation }\end{array}$ & & & & & & & & & & & \\
\hline $\begin{array}{l}\text { Low cord to } \\
\text { bed length }\end{array}$ & & & & & & & & & & & \\
\hline Station & & & & & & & & & & & \\
\hline Feature & & & & & & & & & & & \\
\hline $\begin{array}{l}\text { Low cord } \\
\text { elevation }\end{array}$ & & & & & & & & & & & \\
\hline $\begin{array}{l}\text { Bed } \\
\text { elevation }\end{array}$ & & & & & & & & & & & \\
\hline $\begin{array}{l}\text { Low cord to } \\
\text { bed length }\end{array}$ & & & & & & & & & & & \\
\hline
\end{tabular}

Source (FEMA, VTAOT, Other)?

Comments:

\begin{tabular}{|l|l|l|l|l|l|l|l|l|l|l|l|}
\hline Station & & & & & & & & & & & \\
\hline Feature & & & & & & & & & & & \\
\hline $\begin{array}{l}\text { Low cord } \\
\text { elevation }\end{array}$ & & & & & & & & & & & \\
\hline $\begin{array}{l}\text { Bed } \\
\text { elevation }\end{array}$ & & & & & & & & & & & \\
\hline $\begin{array}{l}\text { Low cord to } \\
\text { bed length }\end{array}$ & & & & & & & & & & & \\
\hline Station & & & & & & & & & & & \\
\hline Feature & & & & & & & & & & & \\
\hline $\begin{array}{l}\text { Low cord } \\
\text { elevation }\end{array}$ & & & & & & & & & & & \\
\hline $\begin{array}{l}\text { Bed } \\
\text { elevation }\end{array}$ & & & & & & & & & & & \\
\hline $\begin{array}{l}\text { Low cord to } \\
\text { bed length }\end{array}$ & & & & & & & & & & & \\
\hline
\end{tabular}




\section{APPENDIX E: \\ LEVEL I DATA FORM}


U. S. Geological Survey

Bridge Field Data Collection and Processing Form

Qa/Qc Check by: $\underline{\mathbf{R B}}$ Date: $10 / 01 / 96$

\section{Structure Number}

ANDOVT00110041

Computerized by: $\underline{\mathbf{R B}}$ Date: $10 / 01 / 96$

Reviewd by: $\quad$ EW Date: $\underline{7 / 01 / 97}$

\section{A. General Location Descriptive}

1. Data collected by (First Initial, Full last name) R. HAMMOND

2. Highway District Number $\mathbf{0 2}$

County WINDSOR (027)

Waterway (l - 6) MIDDLE BR. WILLIAMS RIVER

Route Number VT11

3. Descriptive comments:

Located 4.0 miles east of junction with VT 121 and about 1.1 miles west of the Andover/Chester town line.
Mile marker $\mathbf{0 0 2 6 7 0}$

Town ANDOVER (01300)

Road Name -

Hydrologic Unit Code: $\mathbf{0 1 0 8 0 1 0 7}$

Date $(M M / D D / Y Y) \underline{09} / \underline{10} / \underline{1996}$ 
18. Bridge Type: 1a

1a- Vertical abutments with wingwalls

$1 \mathrm{~b}$ - Vertical abutments without wingwalls

2- Vertical abutments and wingwalls, sloping embankment Wingwalls parallel to abut. face

3- Spill through abutments

4- Sloping embankment, vertical wingwalls and abutments

Wingwall angle less than $90^{\circ}$.

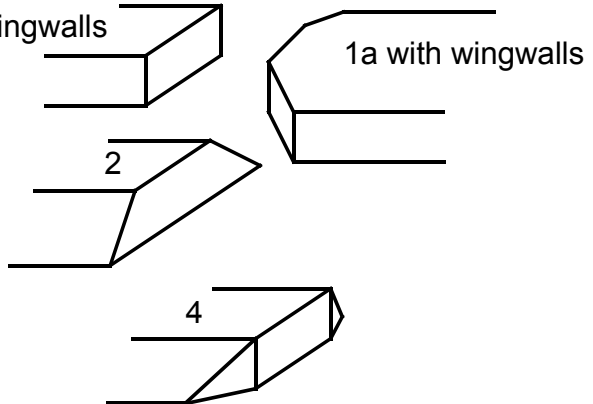

19. Bridge Deck Comments (surface cover variations, measured bridge and span lengths, bridge type variations, approach overflow width, etc.)

4. The immediate banks are all tree covered. On the upstream left and right banks there are houses and lawns. On the right bank downstream there is a house and lawn and a fence with pine trees along Vermont 11. The right bank downstream is forest.

7. Values are from the Vermont AOT files. Measured bridge length is $45.8 \mathrm{ft}$ downstream and $45.9 \mathrm{ft}$ upstream, span length is $\mathbf{4 2 . 8} \mathrm{ft}$ downstream and $42.9 \mathrm{ft}$ upstream, and the bridge width is $30.1 \mathrm{ft}$ from curb to curb and $34.9 \mathrm{ft}$ between the outsides of bridge deck.

13. On the left bank upstream there is a very small tributary at the base of the road embankment that has type 2 protection.

\section{Upstream Channel Assessment}

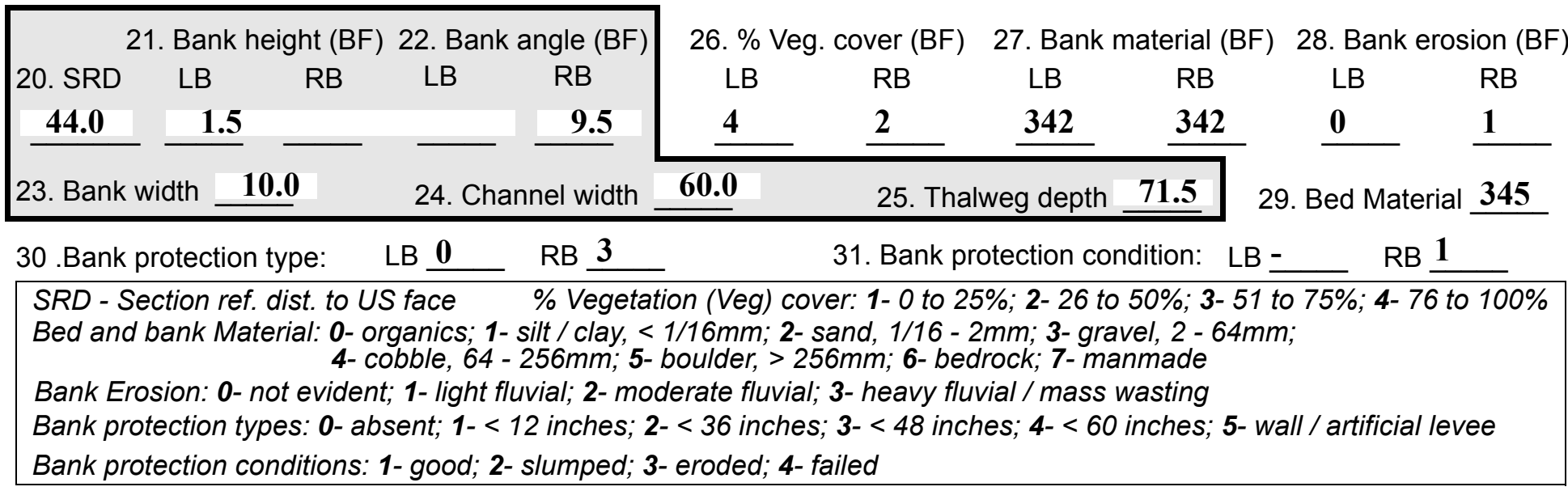

32. Comments (bank material variation, minor inflows, protection extent, etc.):

30. The right bank protection is from $10 \mathrm{ft}$ upstream to $50 \mathrm{ft}$ upstream.

At $300 \mathrm{ft}$ upstream the channel starts to widen and the gradient becomes flatter as it goes through a 120 degree bend to the left. At this location in the channel, the bed material is smaller. High banks on both sides have trees of at least $1 \mathrm{ft}$ in diameter. 

feet $\underline{\mathbf{U B}}$ (US, UB, DS) positioned $\mathbf{0}$ $\%$ LB to 40 $\% R B$

37. Material: $\mathbf{3 4 2}$

38. Point or side bar comments (Circle Point or Side; Note additional bars, material variation, status, etc.):

There is also a channel bar from $190 \mathrm{ft}$ upstream to $25 \mathrm{ft}$ upstream with a width of $16 \mathrm{ft}$ and a mid-bar distance of $80 \mathrm{ft}$ upstream. It is positioned from $50 \%$ left bank to $70 \%$ right bank, at its widest point. The channel bar has grass and woody vegetation growing on it.

39. Is a cut-bank present? $\mathbf{Y}$ (Y or if $N$ type ctrl-n cb) 40. Where? RB (LB or RB)

41. Mid-bank distance: $\mathbf{6 5}$ 42. Cut bank extent: 175 feet $\underline{\mathrm{US}}$ (US, UB) to $\underline{\mathbf{3 5}}$ feet $\underline{\mathbf{U S}}$ (US, UB, DS)

43. Bank damage: 2 (1- eroded and/or creep; 2- slip failure; 3- block failure)

44. Cut bank comments (eg. additional cut banks, protection condition, etc.):

At the downstream end of the cut-bank, large chunks of concrete have been placed to establish some stability along the cut-bank.

45. Is channel scour present? $\mathbf{N}$ (Y or if $N$ type ctrl-n cs)

47. Scour dimensions: Length Width Depth :-

Position 46. Mid-scour distance: -

48. Scour comments (eg. additional scour areas, local scouring process, etc.):

NO CHANNEL SCOUR

49. Are there major confluences? $\mathbf{N}$

51. Confluence 1: Distance Confluence 2: Distance 52. Enters on Enters on 54. Confluence comments (eg. confluence name):

NO MAJOR CONFLUENCES

A minor ephemeral tributary is on the left bank at $20 \mathrm{ft}$ upstream.
50. How many? -

53. Type(1- perennial; 2- ephemeral) Type (1- perennial; 2- ephemeral)

\section{Under Bridge Channel Assessment}

55. Channel restraint (BF)? LB 2

\begin{tabular}{|ccc}
\hline \multicolumn{2}{|c|}{ 56. Height (BF) } & \multicolumn{2}{c}{57 Angl } \\
LB & RB & LB \\
$\mathbf{5 9 . 5}$ & & \\
\hline
\end{tabular}

58. Bank width (BF) (1- natural bank; 2- abutment; 3- artificial levee)

Bed and bank Material: 0- organics; 1- silt / clay, < 1/16mm; 2- sand, 1/16 - 2mm; 3- gravel, 2 - 64mm; 4- cobble, 64 - 256mm; 5- boulder, > 256mm; 6- bedrock; 7- manmade

Bank Erosion: 0- not evident; 1- light fluvial; 2- moderate fluvial; 3- heavy fluvial / mass wasting

64. Comments (bank material variation, minor inflows, protection extent, etc.):

345

The bridge deck was widened and steel I beams were added at the upstream and downstream bridge faces. Upstream, the concrete low chord is $0.6 \mathrm{ft}$ lower than the steel and downstream it is only $0.4 \mathrm{ft}$ lower. The difference between the steel low chord and its bridge seat is $0.2 \mathrm{ft}$. 
65. Debris and Ice Is there debris accumulation?

(Yor $N)$ 66. Where? $\underline{Y}$

(1- Upstream; 2- At bridge; 3- Both)

67. Debris Potential 1 (1- Low; 2- Moderate; 3- High)

68. Capture Efficiency 2 (1-Low; 2- Moderate; 3- High)

69. Is there evidence of ice build-up? 1 (Y or N)

Ice Blockage Potential $\mathbf{N}$

(1-Low; 2-Moderate; 3- High)

70. Debris and Ice Comments:

1

There is some debris caught on boulders and trees in the upstream reach.

\begin{tabular}{|l|c|c|c|c|c|c|c|c|}
\hline Abutments & $\begin{array}{c}\text { 71. Attack } \\
\angle \text { (BF) }\end{array}$ & $\begin{array}{c}\text { 72. Slope } \angle \\
\text { (Qmax) }\end{array}$ & $\begin{array}{c}\text { 73. Toe } \\
\text { loc. (BF) }\end{array}$ & $\begin{array}{c}\text { 74. Scour } \\
\text { Condition }\end{array}$ & $\begin{array}{c}75 . \text { Scour } \\
\text { depth }\end{array}$ & $\begin{array}{c}\text { 76. Exposure } \\
\text { depth }\end{array}$ & 77. Material & 78. Length \\
\hline LABUT & & $\mathbf{3 5}$ & $\mathbf{9 0}$ & $\mathbf{2}$ & $\mathbf{2}$ & $\mathbf{0 . 8}$ & $\mathbf{0 . 8 5}$ & $\mathbf{9 0 . 0}$ \\
\hline RABUT & $\mathbf{1}$ & $\mathbf{0}$ & $\mathbf{9 0}$ & & & $\mathbf{2}$ & $\mathbf{0}$ & $\mathbf{4 2 . 0}$ \\
\hline
\end{tabular}

Pushed: $L B$ or RB

Toe Location (Loc.): 0- even, 1- set back, 2- protrudes

Scour cond.: 0- not evident; 1- evident (comment); 2- footing exposed; 3-undermined footing; 4- piling exposed; 5- settled; 6- failed

Materials: 1- Concrete; 2- Stone masonry or drywall; 3- steel or metal; 4- wood

79. Abutment comments (eg. undermined penetration, unusual scour processes, debris, etc.):

-

1

Average thalweg is $0.5 \mathrm{ft}$. The left abutment footing is above the new footing extending from $26 \mathrm{ft}$ under the bridge (from the upstream bridge face) to $36 \mathrm{ft}$ under the bridge (from the upstream bridge face). The old footing is from $9 \mathrm{ft}$. under the bridge to $26 \mathrm{ft}$. under the bridge. At the junction of the two footings at $26 \mathrm{ft}$ under the bridge (from the upstrean bridge face), there is a cavity and the old footing is undermined. The exposure depth is 1.4ftgandpentration is 1 ft. When the bridge was widened, the footings were extended

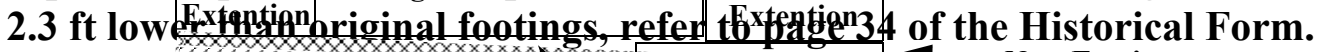

Channel Bed Original LABUT Footing

80. Wingwalls:

$$
\begin{array}{lllll}
\text { Exist? Material? } & \text { Scour } & \text { Scour Exposure } & \text { Angle? Length? } \\
& \text { Condition? } & \text { depth? } \\
& \text { depth? }
\end{array}
$$

USLWW:

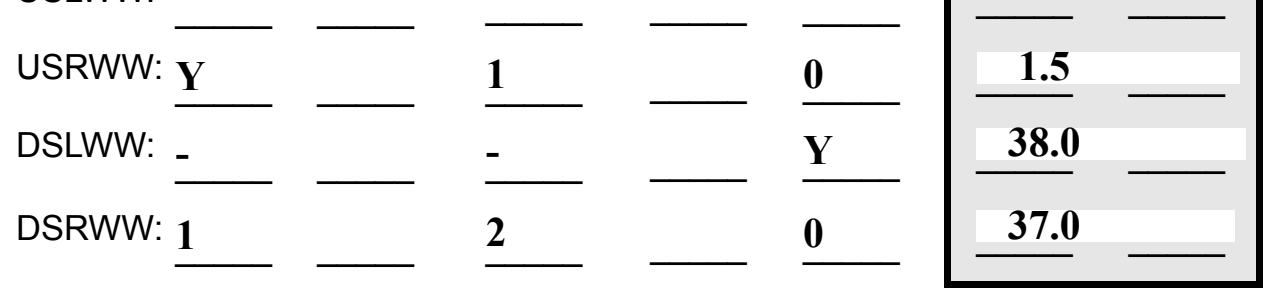

Wingwall materials: 1- Concrete; 2- Stone masonry or drywall; 3- steel or metal; 4- wood

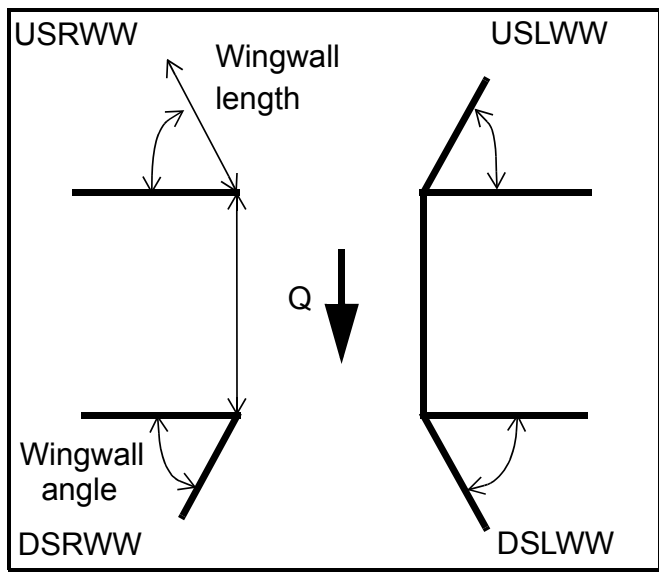

82. Bank / Bridge Protection:

\begin{tabular}{|l|l|l|l|l|l|l|c|c|}
\hline Location & USLWW & USRWW & LABUT & RABUT & LB & RB & DSLWW & DSRWW \\
\hline Type & $\mathbf{0}$ & $\mathbf{2}$ & $\mathbf{Y}$ & - & $\mathbf{1}$ & $\mathbf{1}$ & - & - \\
\hline Condition & $\mathbf{Y}$ & $\mathbf{0 . 8}$ & $\mathbf{1}$ & - & $\mathbf{2}$ & $\mathbf{2}$ & - & - \\
\hline Extent & $\mathbf{1}$ & $\mathbf{0 . 8 5}$ & $\mathbf{0}$ & $\mathbf{2}$ & $\mathbf{3}$ & $\mathbf{0}$ & $\mathbf{0}$ & - \\
\hline
\end{tabular}

Bank / Bridge protection types: 0- absent; 1- < 12 inches; 2- < 36 inches; 3- < 48 inches; 4- < 60 inches; 
83. Wingwall and protection comments (eg. undermined penetration, unusual scour processes, etc.):

-
-
-
-
-
2
1
3
2
1
3

\section{Piers:}

84. Are there piers? 80. (Y or if $N$ type ctrl-n pr)

\begin{tabular}{|l|l|l|l|l|l|l|l|}
\hline \multirow{2}{*}{$\begin{array}{l}85 . \\
\text { Pier no. }\end{array}$} & \multicolumn{3}{|c|}{ width (w) feet } & \multicolumn{3}{c|}{ elevation (e) feet } \\
\cline { 2 - 8 } & w1 & w2 & w3 & e@w1 & e@w2 & e@w3 \\
\hline Pier 1 & & & & $\mathbf{4 0 . 0}$ & $\mathbf{1 1 . 0}$ & $\mathbf{4 5 . 0}$ \\
\hline Pier 2 & & & & $\mathbf{1 1 . 0}$ & $\mathbf{4 5 . 0}$ & $\mathbf{1 1 . 5}$ \\
\hline Pier 3 & & & - & $\mathbf{4 5 . 0}$ & $\mathbf{1 1 . 5}$ & - \\
\hline Pier 4 & - & - & - & - & - & - \\
Nyyyy
\end{tabular}

\begin{tabular}{|l|l|l|l|l|}
\hline Level 1 Pier Descr. & \multicolumn{1}{|c|}{1} & \multicolumn{1}{|c|}{2} & \multicolumn{1}{|c|}{3} & 4 \\
\hline 86. Location (BF) & The & wall & w & \\
\hline 87. Type & top & is & the & \\
\hline 88. Material & of & expo & imm & \\
\hline 89. Shape & the & sed & edi- & \\
\hline 90. Inclined? & foot- & but & ate & \\
\hline 91. Attack $\angle$ (BF) & ing & the & grad & \\
\hline 92. Pushed & of & strea & e of & N \\
\hline 93. Length (feet) & - & - & - & - \\
\hline 94. \# of piles & the & mwa & the & - \\
\hline 95. Cross-members & upst & rd & bed. & - \\
\hline 96. Scour Condition & ream & edge & & - \\
\hline 97. Scour depth & right & is & & - \\
\hline 98. Exposure depth & wing & belo & & - \\
\hline
\end{tabular}

LFP, LTB, LB, MCL, MCM, MCR, RB, RTB, RFP

1- Solid pier, 2-column, 3- bent

1-Wood; 2- concrete; 3- metal; 4- stone

1- Round; 2- Square; 3- Pointed

Y-yes; $N$ - no

$L B$ or $R B$

0- none; 1- laterals; 2- diagonals; 3- both

0- not evident; 1- evident (comment);

2- footing exposed; 3- piling exposed;

4- undermined footing; 5- settled; 6- failed 
99. Pier comments (eg. undermined penetration, protection and protection extent, unusual scour processes, etc.):

-
-
-
-
-
-
-
-
-

100.

\section{E. Downstream Channel Assessment}

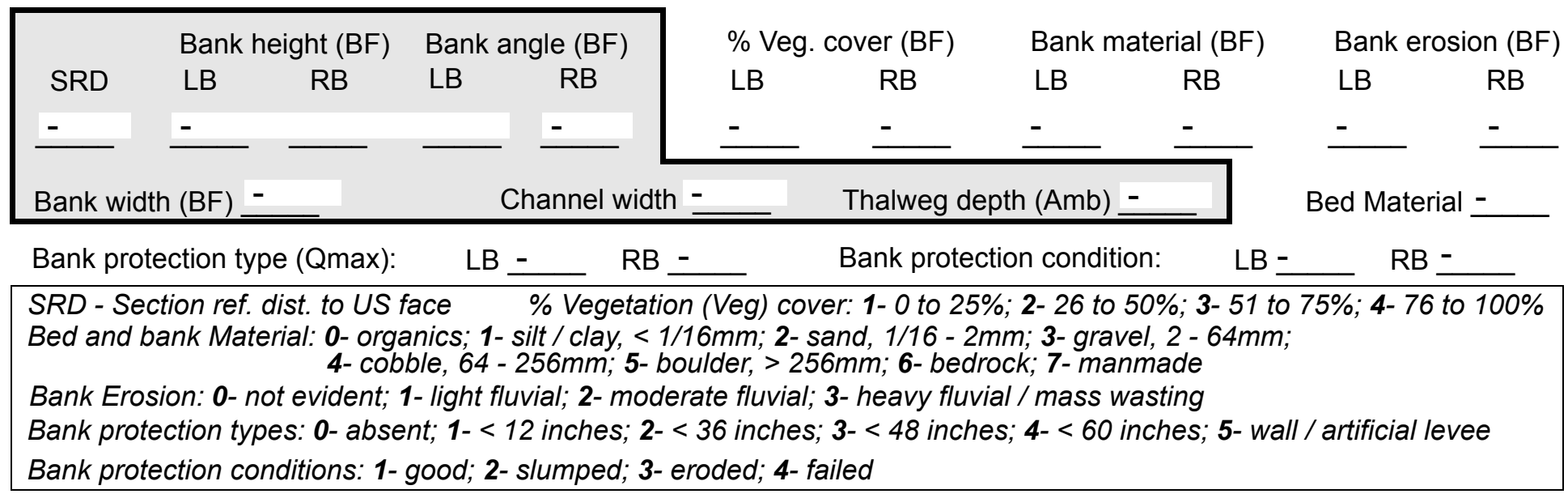

Comments (eg. bank material variation, minor inflows, protection extent, etc.):

$$
\text { - }
$$

$-$

$-$

$-$

$-$

$-$

$-$

$-$

$-$

$-$

$-$

$-$

$-$

$-$

$-$

101. Is a drop structure present? _ ( $Y$ or $N$, if $N$ type ctrl-n ds) 102. Distance: ___ feet 103. Drop: -_ feet 104. Structure material: ___ (1- steel sheet pile; 2- wood pile; 3- concrete; 4- other) 105. Drop structure comments (eg. downstream scour depth):

$-$

-

$-$

$-$

NO PIERS 
106. Point/Side bar present? (Y or $N$. if $N$ type ctrl-n pb)Mid-bar distance:

Mid-bar width:

Point bar extent: feet

(US, UB, DS) to feet (US, UB, DS) positioned $\%$ LB to $\% \mathrm{RB}$

Point or side bar comments (Circle Point or Side; note additional bars, material variation, status, etc.):

\section{4}

34

34

2

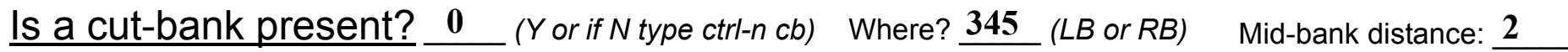
Cut bank extent: $\underline{\mathbf{0}}$ feet $\underline{\mathbf{3}}$ (US, UB, DS) to -_ feet $\underline{\mathbf{T h}}$ (US, UB, DS)

Bank damage: ere (1- eroded and/or creep; 2- slip failure; 3- block failure)

Cut bank comments (eg. additional cut banks, protection condition, etc.):

is evidence of bank protection from $10 \mathrm{ft}$ downstream to $100 \mathrm{ft}$ downstream on the left bank. Between $20 \mathrm{ft}$ downstream and $60 \mathrm{ft}$ downstream the protection is eroded.

Is channel scour present? ( $Y$ or if $N$ type ctrl-n cs)

Mid-scour distance:

Scour dimensions: Length Width Depth:

Positioned $\%$ LB to $\%$ RB

Scour comments (eg. additional scour areas, local scouring process, etc.):

Are there major confluences? $\mathbf{N}$ ( $Y$ or if $N$ type ctrl-n $m c)$

Confluence 1: Distance NO

Confluence 2: Distance $\underline{\text { STR }}$

Confluence comments (eg. confluence name):

RE
Enters on $\underline{\mathbf{D R}}$ ( $L B$ or $R B)$

Enters on $\underline{\mathbf{U C}}$ (LB or RB)
How many? -

Type $\underline{\text { OP }}$ (1- perennial; 2- ephemeral)

Type $\underline{\mathbf{T U}}$ (1-perennial; 2- ephemeral)

\section{F. Geomorphic Channel Assessment}

107. Stage of reach evolution
1- Constructed

2- Stable

3- Aggraded

4- Degraded

5- Laterally unstable

6- Vertically and laterally unstable 
108. Evolution comments (Channel evolution not considering bridge effects; See HEC-20, Figure 1 for geomorphic descriptors):

Y

100

30

5

UB

160

DS

30

100

345 


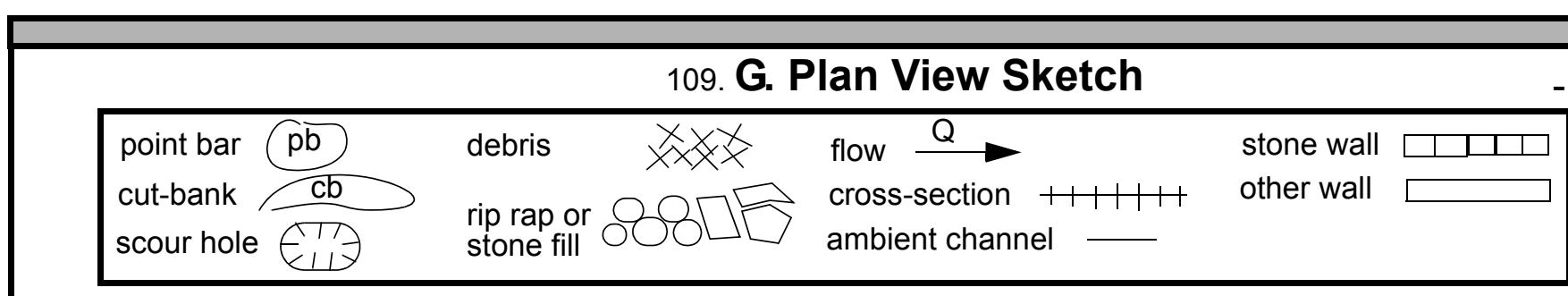


APPENDIX F:

SCOUR COMPUTATIONS 
SCOUR COMPUTATIONS

\begin{tabular}{|c|c|c|c|}
\hline Structure Number: ANDOVT00110041 & & Town: & \\
\hline VERMONT 11 & & County: & WINDSOR \\
\hline Stream: MIDDLE BRANCH WILLIAMS RI & & & \\
\hline Initials ECW & Checked: & SAO & \\
\hline alysis of contraction scour, liv & ed or $\mathrm{cl}$ & ear wat & \\
\hline $\begin{array}{l}\text { Critical Velocity of Bed Material } \\
\mathrm{VC}=11.21^{*} \mathrm{Y}^{\wedge} 0.1667 * \mathrm{D} 50^{\wedge} 0.33 \text { with } \mathrm{S}\end{array}$ & $\begin{array}{l}\text { converted } \\
=2.65\end{array}$ & to Engl & sh units) \\
\hline (Richardson and others, 1995, p. 2 & , eq. 16) & & \\
\hline Approach Section & & & \\
\hline Characteristic & $100 \mathrm{yr}$ & $500 \mathrm{yr}$ & other Q \\
\hline Total discharge, cfs & 3270 & 4810 & 4010 \\
\hline Main Channel Area, ft2 & 432 & 587 & 518 \\
\hline Left overbank area, ft2 & 375 & 758 & 576 \\
\hline Right overbank area, ft2 & 0 & 5 & 0 \\
\hline Top width main channel, ft & 51 & 52 & 52 \\
\hline Top width L overbank, ft & 111 & 151 & 130 \\
\hline Top width $\mathrm{R}$ overbank, ft & 0 & 45 & 0 \\
\hline D50 of channel, ft & 0.279 & 0.279 & 0.279 \\
\hline D50 left overbank, ft & -- & -- & -- \\
\hline D50 right overbank, ft & -- & -- & -- \\
\hline $\mathrm{y}_{1}$, average depth, $\mathrm{MC}$, ft & 8.5 & 11.3 & 10.0 \\
\hline Y1, average depth, LOB, ft & 3.4 & 5.0 & 4.4 \\
\hline Y1, average depth, ROB, ft & ERR & 0.1 & ERR \\
\hline Total conveyance, approach & 71944 & 142267 & 108606 \\
\hline Conveyance, main channel & 45841 & 73568 & 60543 \\
\hline Conveyance, LOB & 26103 & 68679 & 48063 \\
\hline Conveyance, ROB & 0 & 19 & 0 \\
\hline Percent discrepancy, conveyance & 0.0000 & 0.0007 & 0.0000 \\
\hline Qm, discharge, $\mathrm{MC}$, cfs & 2083.6 & 2487.3 & 2235.4 \\
\hline Q1, discharge, LOB, Cfs & 1186.4 & 2322.0 & 1774.6 \\
\hline Qr, discharge, ROB, cfs & 0.0 & 0.6 & 0.0 \\
\hline Vm, mean velocity $\mathrm{MC}$, ft/s & 4.8 & 4.2 & 4.3 \\
\hline $\mathrm{Vl}$, mean velocity, LOB, ft/s & 3.2 & 3.1 & 3.1 \\
\hline Vr, mean velocity, ROB, ft/s & ERR & 0.1 & ERR \\
\hline Vc-m, crit. velocity, MC, ft/s & 10.5 & 11.0 & 10.7 \\
\hline Vc-l, crit. velocity, LOB, ft/s & ERR & ERR & ERR \\
\hline Vc-r, crit. velocity, ROB, ft/s & ERR & ERR & ERR \\
\hline Results & & & \\
\hline Live-bed(1) or Clear-Water(0) Cont & action $\mathrm{Sc}$ & our? & \\
\hline Main Channel & 0 & 0 & 0 \\
\hline Left Overbank & $\mathrm{N} / \mathrm{A}$ & $\mathrm{N} / \mathrm{A}$ & $\mathrm{N} / \mathrm{A}$ \\
\hline Right Overbank & $\mathrm{N} / \mathrm{A}$ & $\mathrm{N} / \mathrm{A}$ & $\mathrm{N} / \mathrm{A}$ \\
\hline
\end{tabular}


Clear Water Contraction Scour in MAIN CHANNEL

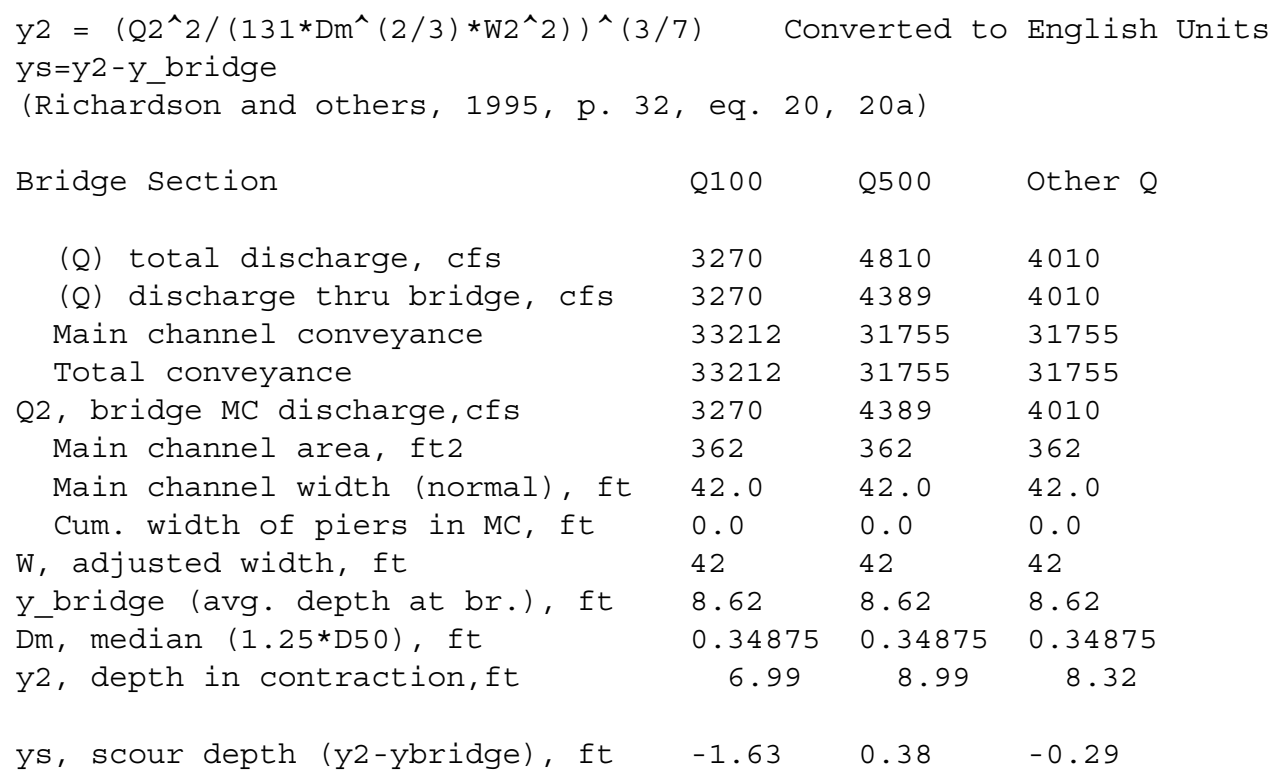


Pressure Flow Scour (contraction scour for orifice flow conditions)

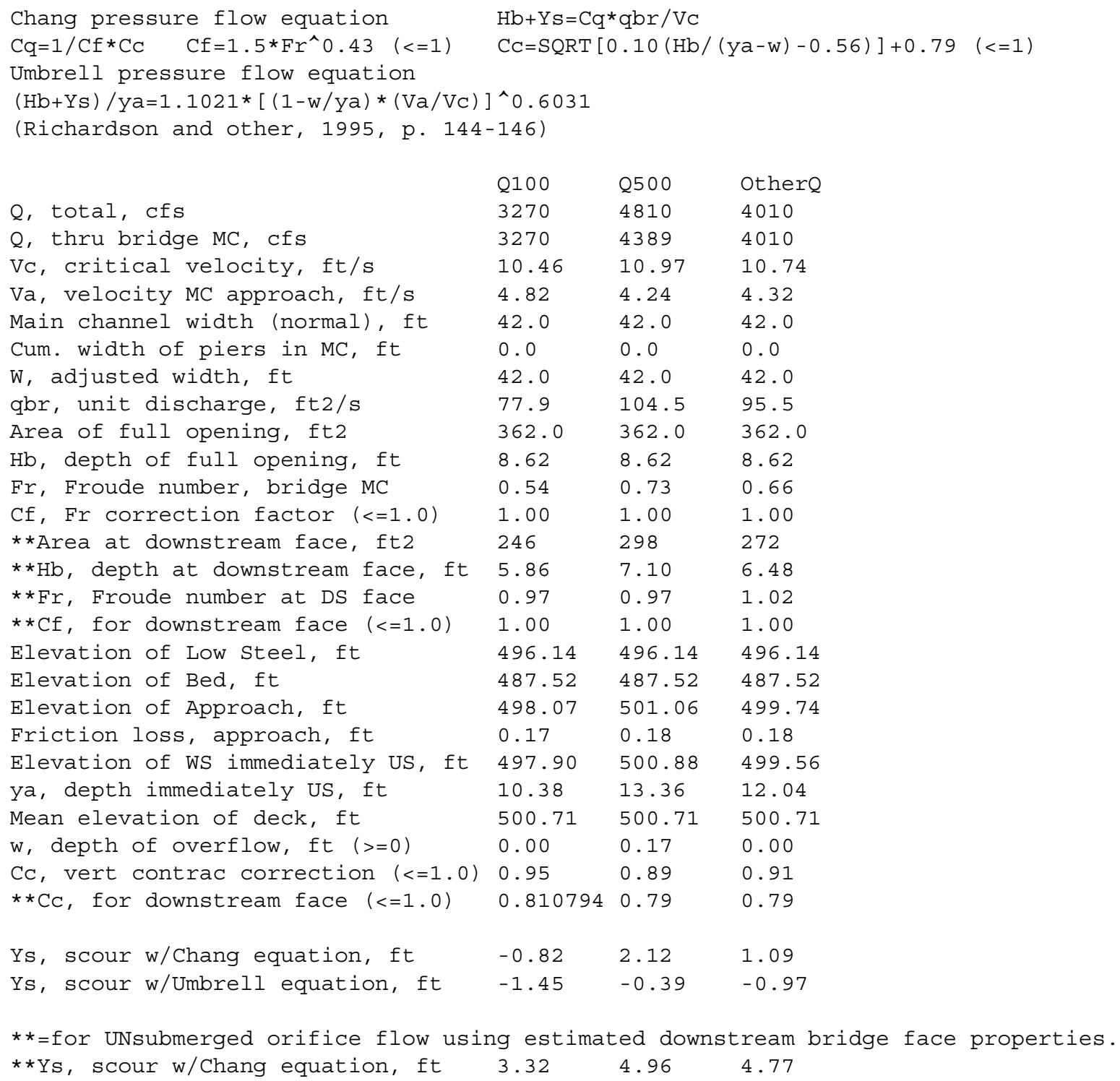




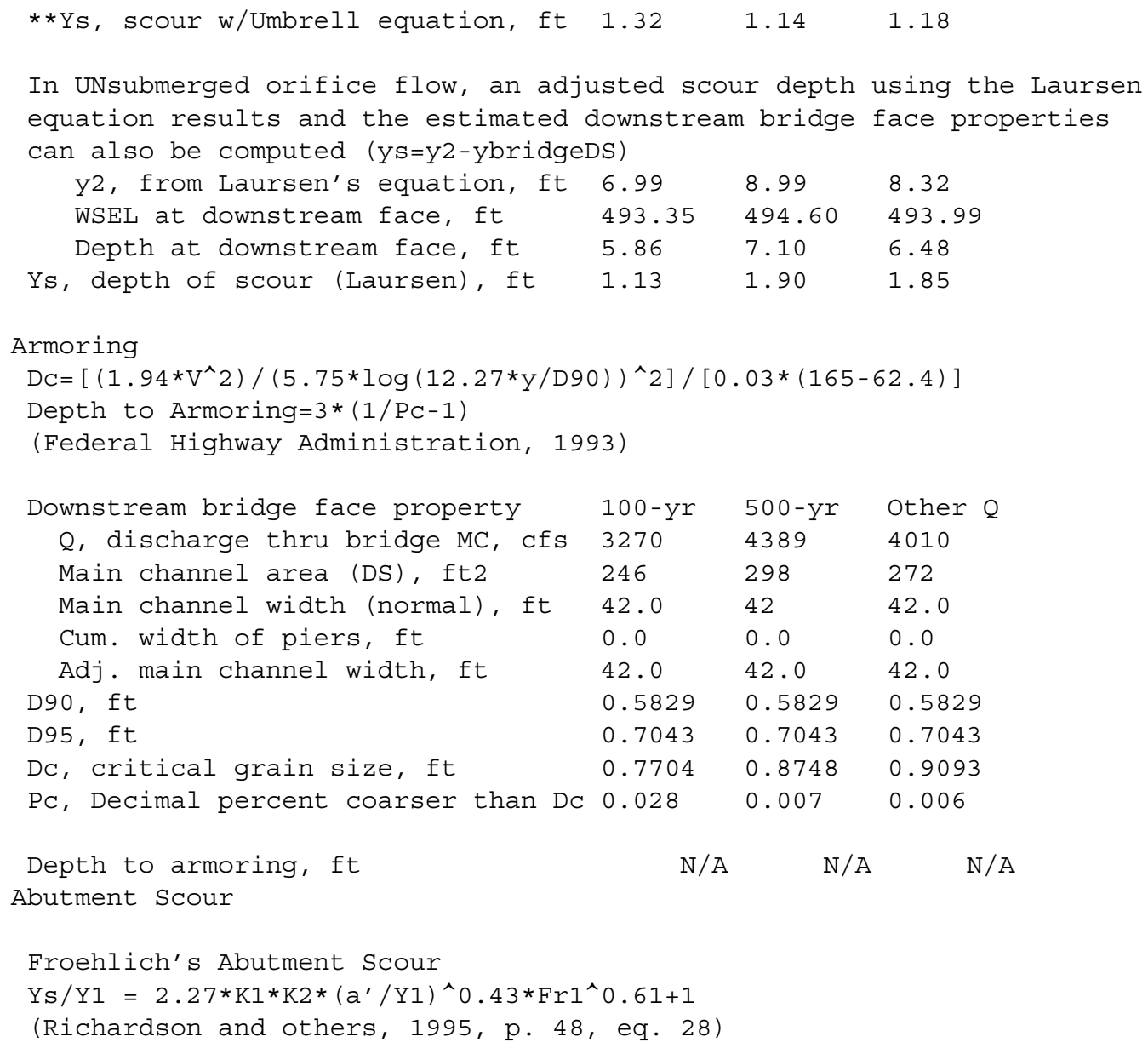




\begin{tabular}{|c|c|c|c|c|c|c|}
\hline$a^{\prime}$ (abut length blocked, ft) & 111.1 & 150.9 & 129.6 & 8.9 & 10.2 & 9.7 \\
\hline y1 (depth f/p flow, ft) & 3.36 & 5.01 & 4.44 & 5.90 & 6.82 & 7.14 \\
\hline$a^{\prime} / y^{1}$ & 33.02 & 30.10 & 29.16 & 1.51 & 1.49 & 1.36 \\
\hline Skew correction (p. 49, fig. 16) & 1.00 & 1.00 & 1.00 & 1.00 & 1.00 & 1.00 \\
\hline Froude no. f/p flow & 0.31 & 0.24 & 0.26 & 0.22 & 0.34 & 0.18 \\
\hline Ys w/ corr. factor K1/0.55: & 16.54 & 22.82 & 20.66 & ERR & ERR & ERR \\
\hline vertical w/ $\mathrm{ww}^{\prime} \mathrm{s}$ & 13.56 & 18.71 & 16.94 & $\mathrm{ERR}$ & $\mathrm{ERR}$ & $\mathrm{ERR}$ \\
\hline spill-through & 9.10 & 12.55 & 11.36 & ERR & ERR & ERR \\
\hline Abutment riprap Sizing & & & & & & \\
\hline Isbash Relationship & & & & & & \\
\hline $\begin{array}{l}\mathrm{D} 50=\mathrm{Y}^{*} \mathrm{~K} * \mathrm{Fr} \mathrm{r}^{\wedge} 2 /(\mathrm{Ss}-1) \text { and } \mathrm{D} 50=\mathrm{Y} * \mathrm{~K} *( \\
\text { (Richardson and others, } 1995, \mathrm{p} 11\end{array}$ & $\begin{array}{r}21 \wedge 0.1 \\
\text { eq. } 81\end{array}$ & $(S s-1)$ & & & & \\
\hline Downstream bridge face property & Q100 & Q500 & Other $\mathrm{Q}$ & Q100 & Q500 & Other $Q$ \\
\hline Fr, Froude Number & 0.97 & 0.97 & 1.02 & 0.97 & 0.97 & 1.02 \\
\hline$y$, depth of flow in bridge, ft & 5.86 & 7.10 & 6.48 & 5.86 & 7.10 & 6.48 \\
\hline Median Stone Diamete & left & utment & & right & abutment, & ft \\
\hline Fr $<=0.8$ (vertical abut.) & ERR & ERR & ERR & ERR & ERR & ERR \\
\hline Fr>0.8 (vertical abut.) & 2.43 & 2.94 & 2.72 & 2.43 & 2.94 & 2.72 \\
\hline
\end{tabular}


